\title{
NEW PROPOSED CHRONOLOGICAL SEQUENCE AND DATES OF COMPOSITION OF ESARHADDON'S BABYLON INSCRIPTIONS
}

\author{
Jamie Novotny (University of Pennsylvania)
}

\begin{abstract}
The Babylon Inscriptions of Esarhaddon, perhaps the best-known group of texts in the extant corpus this seventhcentury Assyrian king, have for decades presented a real challenge in cracking the various levels of ideology imbedded in their contents, as well as the chronological order in which they were written. The latter issue is closely tied to the fact that several clay prisms inscribed with these texts are all dated by the formula šanat rēšs šarrūti, "accession year." This paper will argue that the intentional dating of the Babylon Inscriptions reflects historical reality and that Esarhaddon's did not deliberately falsify the dates of inscriptions. It will also closely examine the contents of the known texts in this small subcorpus of this Assyrian king's official inscriptions and suggest new dates of composition for each text (especially Babylon A and Babylon D), as well as a new chronological sequencing of the inscriptions. Lastly, this paper will present updated editions of Babylon G and Babylon F based on an old nonphysical join proposed by A. R. Millard and a new international join discovered by the author.
\end{abstract}

The reign of Esarhaddon initially got off to a very rocky start. ${ }^{1}$ On the twentieth of Tebētu (X) 681, the sixtysomething-year-old Sennacherib was murdered in Nineveh by one of his sons. Shortly thereafter, civil war broke out, with several brothers vying for the Assyrian throne. ${ }^{2}$ Esarhaddon, who appears to have had popular support

I would like to thank the National Endowment for the Humanities for funding the Royal Inscriptions of the Neo-Assyrian Period (RINAP) Project. I would also like to express my gratitude to Professor Grant Frame (director of the RINAP Project), Dr. Mikko Luukko, and Dr. Greta Van Buylaere for reviewing this manuscript. Their time and care are greatly appreciated. Any errors or omissions are solely my responsibility.

1. Unless it is stated otherwise, the dates given in this article (excluding those in bibliographical citations) are all BCE. Each ancient Mesopotamian year has been given a single Julian year equivalent even though the ancient year actually encompassed parts of two Julian years, with the ancient year beginning around the time of the vernal equinox. For example, the seventh regnal year of Esarhaddon is indicated to be 674, although it actually began at the end of March in 674 and ended in mid-April 673, and thus events that took place late in the ancient year "674" actually took place early in the Julian year 673. For additional details, see E. Leichty, The Royal Inscriptions of Esarhaddon, King of Assyria (680-669 BC), RINAP 4 (Winona Lake, IN: Eisenbrauns, 2011), 5-6. The term "Babylon Inscription” here always refers to texts of Esarhaddon composed for Babylon and Episode(s) (followed by a number) always refers to episode number(s) assigned to passage(s) in those inscriptions in R. Borger, Die Inschriften Asarhaddons Königs von Assyriens (Graz: Archiv für Orientforschung, 1956), 10-29 \$11. When regnal years are cited here, they are always used for Esarhaddon's reign in Assyria, and never to denote a year that this Assyrian king was the de facto ruler of Babylon.

2. See, for example, A. K. Grayson and J. Novotny, The Royal Inscriptions of Sennacherib, King of Assyria (704-681 BC), Part 2, RINAP 3/2 (Winona Lake, IN: Eisenbrauns, 2014), 28-29. 
among the Assyrians, rushed home from his self-imposed exile in the west, entered Nineveh in early Addaru (XII), chased off any pretender to the throne who remained in the capital, and ascended the throne of Assyria, just as his father had intended. ${ }^{3}$ Esarhaddon ruled over Assyria and Babylonia from Addaru (XII) 681 until Arahsamna (VIII) 669.

During his twelve years as king of Assyria and de facto ruler of Babylon, Esarhaddon had his scribes write out numerous inscriptions commemorating his accomplishments both on and off the battlefield in Akkadian (the Standard Babylonian literary dialect), as well as in monolingual Sumerian. No fewer than 143 certain texts of his are known today and E. Leichty has recently published editions of all of these. Esarhaddon's so-called Babylon Inscriptions (see below) are among the best known of his official inscriptions and they are of great interest not only to Assyriologists, but also to biblicists and historians. Their appeal to the modern scholar is due in part to the fact that they present a challenge in cracking the order in which they were composed and the various levels of royal ideology imbedded in their contents. The issues of divine anger, retribution, and reconciliation presented in them are also major points of interest and debate.

Although scholars have carefully investigated Esarhaddon's Babylon Inscriptions, there is much information that can still be gleaned from those texts. Two problems in particular have been especially vexing: (1) the meaning of the date recorded on some of the prisms inscribed with them, which in every instance is Esarhaddon's accession year (šanat rēšs šarrūti), an at most twenty-two-day period in 681; and (2) the chronological sequence of those inscriptions, which, despite the date written on them, were clearly not all written at the same time or even at the beginning of his reign. The date on the Babylon Inscriptions has been sometimes regarded as blatantly inaccurate or deliberately falsified and used by the Assyrian king to exhibit his piety towards the god Marduk, demonstrating that Esarhaddon had turned his attention towards restoring Babylon and its principal temple Esagil from his very first days as king. ${ }^{5}$ As to dating of the texts within Esarhaddon's twelve-year reign, M. Cogan has suggested that the Babylon Inscriptions are to be arranged in a broad chronological sequence from his short accession year (681) to his seventh regnal year (674). He regarded Babylon $G$ as the earliest inscription and Babylon $C$ and Babylon F as the latest inscriptions. ${ }^{6}$ B. N. Porter has proposed that their dates of composition seem to have clustered in two periods: the first group being written at the beginning of Esarhaddon's reign and the second group being composed in 674 or shortly thereafter, but before 672 . She thought that Babylon $\mathrm{G}$ was composed in the second month of 680 ; Babylon D written shortly thereafter; Babylon A and Babylon B ca. 680-678; and Babylon C, Babylon F, and Babylon $\mathrm{E}$ in 674 or a little later (673). ${ }^{7}$ However, a further, in-depth examination of Esarhaddon's Babylon Inscriptions in light of Leichty's new editions, reveals that the Babylon Inscriptions were probably composed from the king's third regnal year (678) to at least his ninth regnal year (672), and possibly down to the end of his reign as king

3. Esarhaddon states in his own inscriptions that he entered Nineveh on the eighth of Addaru (XII), but a Babylonian Chronicle records that unrest in Assyria ended on the second of that month and that Esarhaddon ascended the throne of Assyria on either the eighteenth or twenty-eighth of Addaru. See respectively Leichty, Royal Inscriptions of Esarhaddon, 14 no. 1 i 87-ii 1; and A. K. Grayson, Assyrian and Babylonian Chronicles, TCS 5 (Locust Valley, NY: Augustin, 1975), 81-82 no. 1 iii 36-38.

4. Leichty, The Royal Inscriptions of Esarhaddon.

5. H. Tadmor ("History and Ideology in the Assyrian Royal Inscriptions," in Assyrian Royal Inscriptions: New Horizons in Literary, Ideological, and Historical Analysis. Papers of a Symposium held in Cetona (Siena), June 26-28, 1980, ed. F. M. Fales, OAC 17 [Rome: Instituto per l'Oriente, 1981], 22) regards this as a "rather extreme example of piety." M. Cogan ("Omens and Ideology in the Babylon Inscription of Esarhaddon," in History, Historiography and Interpretation: Studies in Biblical and Cuneiform Literatures, ed. H. Tadmor and M. Weinfeld [Jerusalem: The Magnes Press, 1986], 87) remarks: “The original date [Esarhaddon's accession year], despite its blatant inaccuracy and, what seems to us, inappropriateness, was preserved in all recensions [of the Babylon Inscriptions]. It served as an exhibit of royal piety, for the rêš šarrūti dating was taken to mean: From his very first days on the throne, Esarhaddon turned to the affairs of Babylon, and with due deliberateness, rapidly completed its reconstruction. Obviously, this ante-dating was thought to have propaganda value, if not with the Babylonians themselves- who must have known what actually had been accomplished in the field-then with the gods." See also B. N. Porter, Images, Power, and Politics: Figurative Aspects of Esarhaddon's Babylonian Policy (Philadelphia: American Philosophical Society, 1993), 170.

6. Cogan, "Omens and Ideology," 85-86. Note that Esarhaddon's accession year actually took place in the year 680 (= March 10-31) and that the key events of Esarhaddon's seventh regnal year took place in the year 673 (= February 23).

7. Porter, Images, Power, and Politics, 170-74. 
of Assyria. Babylon $\mathrm{G}$ is still regarded as the earliest known of this group and Babylon D and Babylon E are now considered as the latest attested Babylon Inscriptions. Moreover, it will be argued here that the intentional dating of these texts to Esarhaddon's accession year reflects historical reality; Esarhaddon did not take Marduk by the hand in a Babylonian akitu-festival during the twelve years that he was the de facto ruler of Babylon and, therefore, he was not able to date his official inscriptions in Babylonia by his regnal years. Therefore, there is no longer reason to assume that this Assyrian king's scribes deliberately falsified the dates of inscriptions.

\section{Brief Overview of the Babylon Inscriptions}

The Babylon Inscriptions of Esarhaddon currently comprise twenty-one texts-twenty-two if one includes the hieroglyphic royal inscription added to several inscribed objects. ${ }^{8}$ They are preserved on seventeen clay prisms and prism fragments, a polished basalt monument, a solid, clay cylinder, five tablet fragments, twenty-eight bricks, and a lapis lazuli cylinder seal. The cylinder, the seal, and the bricks were discovered at Babylon itself, whereas the prisms, the tablets, and the cuboid monument were excavated at Aššur and Nineveh or were purchased; most of the purchased prisms and prism fragments are registered as coming from Hillah (ancient Sippar), although E. A. W. Budge states that he bought a few of them at Babylon. With regard to the prisms, the southern Mesopotamian ones are solid, whereas the northern, Assyrian ones are hollow. ${ }^{9}$ The number of inscribed surfaces on the prisms varies from five to ten columns. ${ }^{10}$ Moreover, a variety of scripts were used to write out the inscriptions: archaizing Neo-Babylonian, contemporary Neo-Babylonian, and Neo-Assyrian. ${ }^{11}$

Of the twenty-one texts in question, the best known and most discussed inscriptions are those written on clay prisms and tablets: Esarhaddon's Babylon A-G. These are Standard Babylonian compositions (with some Assyrianisms) that have narrative accounts of the rebuilding of Babylon and Esagil ("House Whose Top Is High") and the circumstances leading up to the destruction of that city and its temples. Copies of some of the inscriptions written on prisms-Babylon A, Babylon C, Babylon E, Babylon G, and the text written on MMA 86.11.283-are dated to Esarhaddon's accession year, which if taken at face value would refer to the last twenty-two (twelve or two) days of 681, too short a period to have done any work at Babylon. ${ }^{12}$ Based on events mentioned in some of these texts, it is certain that some of the inscriptions could not have been written earlier than Addaru (XII) 674 (his seventh regnal year). Moreover, the scribe of the one known copy of Babylon G added that he had that prism inscribed in the month Ayyāru (II), which at the earliest would have been the second month of the year 680 (Esarhaddon's first

8. Leichty, Royal Inscriptions of Esarhaddon, 193-258 nos. 104-126; and I. Spar and M. Jursa, The Ebabbar Temple Archive and Other Texts from the Fourth to First Millennium B.C., CTMMA 4 (Winona Lake, IN: Eisenbrauns, 2014), 257-70 and pls. 121-127 nos. 156-61 (editions by Leichty and copies by Spar). I assume that Royal Inscriptions of Esarhaddon, nos. 108 and 109 are part of one and the same text (see below) and that Royal Inscriptions of Esarhaddon, nos. 116 and 117 contain different inscriptions; I also treat the two inscriptions of Royal Inscriptions of Esarhaddon, no. 118 as a single text. This also assumes that Royal Inscriptions of Esarhaddon, no. 112 belongs to this group of texts, for which there is little evidence; note that the author doubts that this text is one of the Babylon Inscriptions and that it was intended for another Babylonian city (see n. 35). Moreover, the eight so-called Ašsur-Babylon texts are excluded here. For those inscriptions, see Leichty, Royal Inscriptions of Esarhaddon, 65-66 no. 18, 100-101 no. 45, 103-15 nos. 48-49 and 51-53, and 134-37 no. 60.

9. Royal Inscriptions of Esarhaddon, nos. 104 exs. 2-3 and nos. 108-109 are parts of hollow prisms. The following are from solid prisms: Royal Inscriptions of Esarhaddon, no. 104 exs. 1 and 4-6, no. 105 exs. 1-2, no. 106 exs. 1-3 and 5-7, no. 107, and nos. 110-12.

10. Royal Inscriptions of Esarhaddon, no. 104 ex. 3, nos. 108-109, and no. 112 are fragments of five-sided prisms. Royal Inscriptions of Esarhaddon, no. 106 exs. 2-3 and 5-7 and no. 110 come from six-sided prisms. Royal Inscriptions of Esarhaddon, no. 104 exs. 1 and 4 are seven-sided prisms. Royal Inscriptions of Esarhaddon, no. 104 exs. 2 and 5, no. 106 ex. 1, and no. 111 are pieces of eight-sided prisms. Royal Inscriptions of Esarhaddon, no. 104 ex. 6, no. 105 exs. 1-2, and no. 107 come from ten-sided prisms. Royal Inscriptions of Esarhaddon, no. 106 ex. 4 is from a multicolumn tablet.

11. Royal Inscriptions of Esarhaddon, no. 104 ex. 1, no. 106 exs. 1-2 and 6-7, and no. 114 are written in an archaizing Neo-Babylonian script. Royal Inscriptions of Esarhaddon, no. 104 exs. 4-5, no. 105 exs. 1-2, no. 106 ex. 4, and nos. 112-13 are written in contemporary Babylonian script. Royal Inscriptions of Esarhaddon, no. 104 exs. 2-3 and 6, no. 106 exs. 3 and 5, nos. 107-11, and nos. 116-17 are written in NeoAssyrian script.

12. See n. 3 for information on the different dates for Esarhaddon assuming power as king of Assyria. 
regnal year). With these facts in mind, most scholars generally do not take the date of the Babylon Inscriptions literally. Since it is presumed that Esarhaddon had all of his Babylon prisms dated to his accession year, scholars have had to rely on internal textual evidence to date them within Esarhaddon's twelve year reign. Each scholar who has carefully studied the Babylon Inscriptions has his/her own dating and chronological ordering of the texts. Having now worked on this group of texts for several years, the time is ripe for the author to readdress how Esarhaddon and his image-makers are dating his Babylon Inscriptions, the span of time during which these texts were written on clay and stone objects, and the order in which the known texts in this small corpus were composed. Before diving head first into these matters, it is necessary to say a few words about the lifespan of individual texts.

\section{For How Long Did Scribes Copy Individual Royal Inscriptions?}

This question is not easy to answer because relatively few late Neo-Assyrian royal inscriptions have their date preserved or were dated in antiquity. From available evidence, Assyrian kings could have several different inscriptions issued within a one-year period for a single project or could use the exact same text for two or more years. In order to assess the production period of a given royal inscription properly, it is necessary to have more than one dated copy of that text, hopefully not with the exact same date, and, better yet, to have one or more dated copies of one of the inscriptions that immediately preceded or followed it.

Four texts of Esarhaddon meet the first set of criteria, but none at present meet the second set. These are Nineveh A, Aššur A, Kalhu A, and Kalhu B. ${ }^{13}$ The two dated copies of Aššur A and the three dated copies of Kalhu B provide evidence that some texts were copied during a two-month period, for a span of at least twenty days. ${ }^{14}$ The two dated copies of Kalhu A show that some official inscriptions were inscribed on clay cylinders during a fourmonth period, for a span of at least seventy-eight days. ${ }^{15}$ More importantly, the dated copies of Nineveh A provide evidence that individual inscriptions could be copied for almost an entire year. ${ }^{16}$ The short duration of some inscriptions can be inferred from Aššur A and the two Aššur B texts. ${ }^{17}$ Although the clay cylinders and clay prisms inscribed with Aššur B are not dated, both texts-which have only one minor deviation in the prologue-were probably written on their respective objects during Esarhaddon's first regnal year (680). The marginally shorter cylinder text was likely replaced by the slightly longer prism text during the course of that year. Aššur A, which was also written on clay prisms, replaced Aššur B by Simānu (III) of his second regnal year (679). Within a year's time, at least three inscriptions were written to commemorate work on the Aššur temple at Ashur.

Several inscriptions of Esarhaddon's father Sennacherib attest to inscriptions being replaced by one or two later versions within a relatively short period of time and to individual texts being copied on objects for long spans of time. During the first eight months of Sennacherib's third regnal year (702), the Assyrian king had at least three

\footnotetext{
13. Respectively Leichty, Royal Inscriptions of Esarhaddon, 9-26 no. 1, 119-129 no. 57, 153-57 no. 77, and 157-60 no. 58.

14. Aššur A ex. 1 is dated to IV-19-679 and Aššur A ex. 3 is dated to III-[...]-679; Kalhu B ex. 1 is dated to VI-10-676; Kalhu B ex. 4 is dated to V-21-676; and Kalhu B ex. 6 is dated to V-25-676. See Leichty, Royal Inscriptions of Esarhaddon, 129 no. 57 and $159-60$ no. 78.

15. Kalhu A ex. 1 is dated to V-5-672 and Kalhu A ex. 6 is dated to II-18-672; see Leichty, Royal Inscriptions of Esarhaddon, 156-57 no. 77.

16. Nineveh A exs. 1, 16, and 27 are dated to XII-673; Nineveh A exs. 2 and 6 are dated to IV?-673; and Nineveh A ex. 29 is dated to I-672. See Leichty, Royal Inscriptions of Esarhaddon, 26 no. 1. None of the exemplars include the day that the prisms were inscribed. Exs. 2 and 6 were inscribed is during the "Month 'Opening of the Gate"' which corresponds to Du' 'uzu (IV). For details, see Leichty, Royal Inscriptions of Esarhaddon, 26. The date of ex. 16 given in Leichty, Royal Inscriptions of Esarhaddon (ibid.) is actually for ex. 6. The date written on ex. 16 is

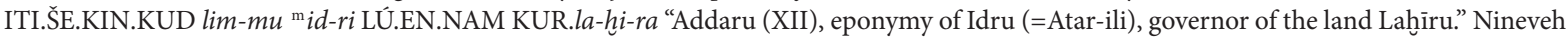
A ex. 7 also has a partially preserved date, which E. Weissert (apud H. Tadmor, "An Assyrian Victory Chant and Related Matters," in From the Upper Sea to the Lower Sea: Studies on the History of Assyria and Babylonia in Honour of A. K. Grayson, ed. G. Frame, PIHANS 101 [Leiden: Nederlands Instituut voor het Nabije Oosten te Leiden, 2004], 274) would like to date to V?-671. Assuming that it is an exemplar of Nineveh A and that Weissert's proposed date is correct, then the period during which Nineveh A was copied onto prisms by Esarhaddon's scribes would have been over two years.
}

17. Leichty, Royal Inscriptions of Esarhaddon, 119-34 nos. 57-59. 
different inscriptions commemorating the construction of his palace at Nineveh written on clay cylinders: the socalled First Campaign Cylinder, the Bellino Cylinder, and an intermediary text that combines elements of both of the aforementioned inscriptions. ${ }^{18}$ Although the objects upon which it was copied are not dated, the First Campaign Cylinder text likely was composed and written on cylinders during the first half of that year. That ninetyfour-line inscription was replaced by a seventy-one-line text shortly thereafter, and that text was in turn replaced a little while later by the sixty-three-line Bellino Cylinder text. Exactly when the First Campaign Cylinder text was replaced by its first successor is not known, but it is certain that sometime during the Elamite month Sibüti (= Arahsamna [VIII]), the Bellino Cylinder text had replaced its immediate predecessor. ${ }^{19}$ The fact that copies of both the inscription that immediately followed the First Campaign Cylinder text and the Bellino Cylinder text were being written on clay foundation documents in the same month clearly shows that different editions of inscriptions commemorating the same building project could be copied onto objects within a very short span of time; in this case, two inscriptions within a thirty-day period. On the other hand, inscriptions could be written on objects for long periods of time. The best example is the so-called Final Edition of the Annals text, which is written on the well known Chicago and Taylor Prisms. ${ }^{20}$ That inscription was written on six-sided clay prisms from at least the twentieth day of Addaru (XII) 691 (Sennacherib's fourteenth regnal year) to at least the month Du'ūzu (IV) 689 (his sixteenth regnal year). Copies of that one text were written on prisms for at least a 460-day period.

So then, for how long did Esarhaddon's scribes write out any given Babylon Inscription? At present-and even if we had additional copies of each text-there is no way to answer this question accurately. Based on the evidence presented above, it is certain that some texts were written on their intended objects for only a short time, perhaps from two or three months to six months, while other texts were inscribed on objects for long periods of time, from over a year to a year and a half. Moreover, copies of two texts for a given project could be inscribed on objects within the same month of the year. Given the fact that all of the known copies of Esarhaddon's Babylon Inscriptions are dated to his accession year, there is no way to tell which texts had a short lifespan and which texts were copied over a long span of time.

\section{Using the Accession Year to Date the Babylon Inscriptions: Ideology, Reality, or Both}

It has been long known that the date written on prisms inscribed with Esarhaddon's Babylon Inscriptions is somewhat unusual and that few, if any, of these official inscriptions were actually composd during this Assyrian king's (at most) twenty-two-day accession year. This is especially clear with Babylon C and Babylon F. Since those two texts contain a reference to an event that two Babylonian chronicles record as having happened on the tenth of Addaru (XII) of Esarhaddon's seventh regnal year (674), neither text could have been composed and written on clay prisms prior to that time. ${ }^{21}$ Thus, as late as Esarhaddon's eighth regnal year (673), the Assyrian king was still having his Babylon Inscriptions dated by his accession year, and there is no mistaking this as anything but intentional. As mentioned earlier, scholars have sometimes regarded this date as blatantly inaccurate or deliberately falsified and used by the Assyrian king as an exhibit of his piety towards the god Marduk, demonstrating that he

18. A. K. Grayson and J. Novotny, The Royal Inscriptions of Sennacherib, King of Assyria (704-681 BC), Part 1, RINAP 3/1 (Winona Lake, IN: Eisenbrauns, 2012), 29-55 nos. 1-3.

19. Copies of text no. 2 and text no. 3 (Bellino Cylinder) are dated to the Elamite month Sibüti, which is the equivalent of Arahsamna (VIII); see Grayson and Novotny, Royal Inscriptions of Sennacherib 1, 47 and 55.

20. Ibid., $167-86$ no. 22. Example 1 is the Chicago Prism and ex. 2 is the Taylor Prism.

21. Some of the plundered gods returned from Assyria and Elam mentioned in Babylon C vii 5-11 (Leichty, Royal Inscriptions of Esarhaddon, 208 no. 105) and Babylon F vii 7-14 (see appendix 2) are mentioned in Grayson, Assyrian and Babylonian Chronicles, 84 no. 1 iv 16-18 and 126 no. 14 rev. 20-22; these are the gods of Agade. 
had turned his attention towards restoring Babylon and Esagil as soon as he became king. ${ }^{22}$ This need not be the case, as the author will argue presently.

H. Tadmor has convincingly argued on several occasions that Akkadian rēššarrūti is "employed not chronologically but in a general sense to mean the early years of a king's reign."23 Specifically, with regard to late NeoAssyrian royal inscriptions, he further elaborates "that the term 'the beginning of kingship' never lost its literary connotation, so that in the days of Sennacherib, when the royal scribes began to abandon the chronological principle of numbering the campaigns by pal $\hat{u}$, they apparently revived the literary use of $r . \check{s}$. [rēššarrūti] (equal to the then obsolete šurrat šarrūti). Thereafter, $r . \check{s}$. was employed intentionally to denote events that took place during the early years of a king's reign. This development is especially evident in some inscriptions of Ashurbanipal where the chronological sequence of the campaigns is very loosely indicated. For example the fall of Thebes-which the Assyrians conquered in his sixth or seventh year-is assigned in Prism F to the $r .{ }^{.}$.”. ${ }^{24}$ In short, rēš šarrūti in NeoAssyrian royal inscriptions had a general, non-calendrical meaning. However, Esarhaddon's scribes dated texts by šanat rēššarrūti, which clearly denotes the accession year, not the early part of his reign and, therefore, something else must be at play here, but what?

There is no question that Esarhaddon deliberately dated his Babylon Inscription to his accession year and that the Assyrian king, who was also the de facto ruler of Babylon, and his image-makers went to great lengths to ensure that Marduk, Babylon's tutelary deity, was not offended by anything Esarhaddon said or did regarding the rebuilding of Babylon and its principal temple. A three-part strategy was, at least initially, put in place. First, Esarhaddon distanced himself from his father, the very man responsible for Babylon's destruction, by not stating that he was the son of Sennacherib in texts composed for objects intended for Babylon. ${ }^{25}$ Second, while rebuilding Marduk's temple, the king claims not to have deviated, even a little bit, from the existing ground plan of that temple. In particular, he explicitly states that he did not diminish Esagil by even a single cubit nor increase it by half a cubit. ${ }^{26}$ The inclusion of such statements in the Babylon Inscriptions shows that Esarhaddon was anxious about righting the wrong done by his father and rebuilding the temple on its former ground plan was seen as one means to that end. ${ }^{27}$ Third and last, having taken the necessary measures not to offend Babylon's tutelary deity with any of the contents of inscriptions displayed or deposited in Esagil and Babylon, it was important to accurately and honestly date the inscribed objects and, therefore, the date written on clay prisms had to be Esarhaddon's "accession year," a date that reflected historical reality.

Although Esarhaddon is named as a ruler of Babylon in several king lists and referred to himself as "king of Babylon" in several inscriptions written (or stamped) on bricks, this Assyrian king never took the hand of the god Marduk during an akitu-festival at Babylon and, although he was the de facto ruler of Babylon, he could not officially begin counting his regnal years as ruler of Babylon. This was because Marduk and his statue were in exile

\section{See n. 5}

23. H. Tadmor, "The Inscriptions of Nabunaid: Historical Arrangement," in Studies in Honor of Benno Landsberger on His Seventy-fifth Birthday, April 21, 1965, ed. H. G. Güterbock and T. Jacobsen, AS 16 (Chicago: University of Chicago Press, 1965), 352. See also J. A. Brinkman, "Merodach-baladan II," in Studies Presented to A. Leo Oppenheim, ed. R. D. Biggs and J. A. Brinkman (Chicago: University of Chicago Press, 1964), 23 n. 126.

24. Tadmor, "Inscriptions of Nabunaid," 353.

25. See Leichty, Royal Inscriptions of Esarhaddon, 194-95 no. 104 i 1-18a, 203 no. 105 i 1-9, 212 no. 106 i 1-9, 222 no. 109 i 1'-12', 231 no. 114 i 1-6, and 247 no. 117 obv. 1'-4'. During the 672-669 period, however, Esarhaddon seems not to have had a problem mentioning that he was the son of Sennacherib; see, for example, ibid., 229 no. 113 lines $4 \mathrm{~b}-5 \mathrm{a}$.

26. Leichty, Royal Inscriptions of Esarhaddon, 198 no. 104 iii $42 \mathrm{~b}-46$ and 206 no. 105 iv 38-v 1.

27. Judging from the archaeological evidence at Ashur, following the former plan(s) of temples appears not to have been a major concern for Assyrian kings. For example, the plans of the Aššur temple and the Ištar temple were changed and/or expanded several times; Esarhaddon's father Sennacherib altered and expanded the former temple. For the plans of those temples, see W. Andrae, Die jüngeren Ischtar-Tempel in Assur, WVDOG 58 (Leipzig: Hinrichs, 1935); and E. Haller, Tempel und Heiligtümer im Alten Mesopotamien: Typologie, Morphologie und Geschichte (Berlin: de Gruyter, 1982), 52-73. Thus, Esarhaddon's statement about not altering the Aššur temple at Ashur and his claim to have had Esagil built precisely according to its former plan should be seen as part of Esarhaddon's reaction to his father's death. Esarhaddon may have seen Sennacherib's murder as divine retribution for altering Ešarra and destroying Babylon and Esagil. 
in the city Ashur and not in a position to confer kingship on Esarhaddon since that coronation ceremony could only take place at Babylon itself. ${ }^{28}$ Despite the fact that Esarhaddon's authority over Sumer and Akkad was recognized, the entire duration of his twelve-year reign as king of Assyria was considered his accession year in Babylon. Thus, the date added to the clay prisms inscribed with this Assyrian king's Babylon Inscriptions reflected historical reality: Esarhaddon's accession year as king of Babylon. Any other date would have been seen as an offense to the recently reconciled and still-in-exile Marduk, the very thing that Esarhaddon was painstakingly trying not to do. Despite the king being anxious about this matter, this particular aspect of historical reality bolstered royal ideology. Thus, during the entirety of twelve of his years as the de facto ruler of Babylon, Esarhaddon could legitimately state that all of his building activities in Babylon took place during his accession year; in Assyria, he could make no such claims. With this fact in mind, there is no longer any reason to assume that the Assyrian king and his imagemakers deliberately falsified the dates of his Babylon Inscriptions.

\section{When Did Esarhaddon Turn His Attention to Rebuilding Babylon and Esagil?}

Because the date included on any inscription intended for Babylon had to be the "accession year" and since Esarhaddon was king for twelve years, the known Babylon Inscriptions could have been composed and written on clay objects anytime between Addaru (XII) 681 and Arahsamna (VIII) 669. There are clues in the texts themselves that indicate that Esarhaddon did not immediately turn his attention to rebuilding Babylon and Esagil.

It is stated in several texts (Babylon A-D) that Marduk had ordered the period of Babylon's abandonment to be changed from seventy years to only eleven years. ${ }^{29}$ If taken at face value, the eleven years would have been from the city's destruction in 689 (Sennacherib's sixteenth regnal year) to 679 (Esarhaddon's second regnal year). ${ }^{30}$ The year 679 as the end of that eleven-year period can be confirmed by the inclusion of a passage (Episode 13) in several inscriptions (Babylon A-C) describing the observation of a heliacal rising of Jupiter in the month Simānu (III), one of the key favorable omens that prompted Esarhaddon to rebuild Babylon and Esagil. According to some scholars, Jupiter rose heliacally at Babylon on the twenty-eighth of Simānu (III) and at Nineveh on the twenty-ninth in 679..$^{31}$ Accepting Esarhaddon's statement about the length of Babylon's abandonment as fact and assuming that the heliacal rising of Jupiter observed in the month Simānu (III) was seen as an auspicious sign to begin rebuilding

28. A few Babylonian texts of his, including several bricks from Babylon itself, call him "king of Babylon"; see Leichty, Royal Inscriptions of Esarhaddon, 250-56 nos. 119-125 and 267-270 nos. 131-132. Moreover, only one economic document from Babylonia clearly gives him the title "king of Babylon"; see L. Jakob-Rost, “Urkunden des 7. Jahrhunderts v. u. Z. aus Babylon," FB 12 (1970), 52-53 no. 3 (VAT 17909) rev. $6 \mathrm{~b}-7^{\mathrm{d}}<a \check{s}>-$ šur-ŠEŠ-MU / 'LUGAL' TIN.TIR.KI (transliteration courtesy of G. Frame). This title is also given to him in two synchronistic king lists; see A. K. Grayson, “Königslisten und Chroniken," RlA 6:116-21, \$3.12 iv 12 and 124-25 $\$ 3.17$ iv 4'. Babylonian chronicles, on the other hand, are careful not to state that Esarhaddon was officially regarded as ruler over Babylonia. For example, Grayson, Assyrian and Babylonian Chronicles, 82 no. 1 iii 38 "Esarhaddon ascended the throne in Assyria"; and ibid., 86 no. 1 iv 32, "Esarhaddon ruled Assyria for twelve years."

29. Leichty, Royal Inscriptions of Esarhaddon, 196 no. 104 ii 2b-9a, 203-4 no. 105 ii 16-22a, 236 no. 114 ii $12-18$, and 245 no. 116 obv. $18^{\prime}-19^{\prime}$. On how seventy in cuneiform could become eleven, see ibid., 196, the note to no. 104 ii 6-7.

30. For this opinion, see J. A. Brinkman, “Through a Glass Darkly: Esarhaddon's Retrospects on the Downfall of Babylon,” JAOS 103 (1983) 36 n. 7. R. Borger (review of H. Schmökel, Das Gilgamesh-Epos, BiOr 29 [1972], 34-35), Cogan (“Omens and Ideology," 85-87), and Porter (Images, Power, and Politics, 170-73) regard the year 680 as the end of the eleven-year period.

31. Leichty, Royal Inscriptions of Esarhaddon, 197 no. 104 ii 34-41a, 204-205 no. 105 iii 10-18, and 245 no. 116 rev. 2-4. For the proposed date of the heliacal rising of Jupiter, see S. De Meis, "Astronomical Dating of Sargon II letters and an Esarhaddon Inscription," AfO 50 (2003-4) 347, where III-28 equals June 27. Compare the astronomical observances in Aššur A i 9'-ii 18, which includes sightings for Venus and Mars, but not for Jupiter; see Leichty, Royal Inscriptions of Esarhaddon, 121-24 no. 57. The earliest known copy of that text (ex. 3) was written in Simānu (III) 679; the day that it was inscribed is now missing. Aššr A is presumed here to have been composed earlier than any of the Babylon Inscriptions. Marduk's primary astral manifestation was Jupiter and the mention of that planet's heliacal rising in connection with Esagil's rebuilding should not come as a surprise. For some details on the association of Marduk with Jupiter, see S. Parpola, Letters from Assyrian Scholars to the Kings Esarhaddon and Assurbanipal, Part 2: Commentary and Appendices, AOAT 5/2 (Neukirchen-Vluyn: Neukirchener Verlag, 1983), 73-74 and 260; and F. Rochberg, "Marduk in Heaven," in Festschrift für Hermann Hunger zum 65. Geburtstag gewidmet von seinen Freunden, Kollegen und Schülern, ed. M. Köhbach, S. Procházka, G.J. Selz, and R. Lohlker, WZKM 97 (Vienna: Institut für Orientalistik, 2007), 433-42. 
Babylon, then it can be inferred that Esarhaddon first gave serious consideration to undertaking construction at Babylon later than previously thought (immediately after he ascending the Assyrian throne). Moreover, this would mean that none of the known Babylon Inscriptions could have been written before that time. Therefore, it is unlikely that the earliest texts in this subcorpus of this Assyrian king's official inscriptions were composed and written on clay prisms at the very beginning of Esarhaddon's first regnal year (680). Thus, the one known copy of Babylon G, a text generally regarded as being the earliest of the Babylon Inscriptions, was probably inscribed in Ayyāru (II) 678 (the king's third regnal year), and not two years earlier as previously suggested.

\section{Proposed Dates and Chronological Sequence of the Babylon Inscriptions}

M. Cogan proposed a broad chronological sequence, from 680 to 674/3, for the Babylon Inscriptions known to him, with the criteria for the early or late placement within that sequence being the information each text contained. ${ }^{32}$ Babylon $\mathrm{G}$ was regarded as being the earliest inscription, and Babylon $\mathrm{C}$ and Babylon $\mathrm{F}$ as the latest inscriptions. B. N. Porter proposed that this same group of texts seems to have clustered in two periods, with the first group being written at the beginning of Esarhaddon's reign and the second group being composed in 674 or shortly thereafter, but before 672.33 Porter thought that Babylon G was composed in Ayyāru (II) 680; Babylon D written shortly thereafter; Babylon A and Babylon B ca. 680-678; and Babylon C, Babylon F, and Babylon E in 674 or 673 . Because none of these aforementioned inscriptions name or refer to the heir designates of Assyria and Babylon, Ashurbanipal and Šamaš-šuma-ukīn respectively, it has been suggested that none of Esarhaddon's Babylon Inscriptions were composed or written on clay prisms between Ayyāru (II) 672 and Arahssamna (VIII) 669..$^{34}$ A further, in-depth examination of Esarhaddon's Babylon Inscriptions not only reveals that these texts were probably composed from Esarhaddon's third regnal year (678) to at least his ninth regnal year (672), but also that their proposed chronological sequence needs to be rearranged. This is especially true for Babylon $\mathrm{D}$, which has generally been thought to have come from the early part of the reign, but in fact that inscription almost certainly comes from the later part of Esarhaddon's reign (see below). The dates of twelve of Esarhaddon's Babylon Inscriptions will be discussed here and, when possible, they will be presented chronologically from earliest to latest. ${ }^{35}$

\section{Babylon $G$}

The text inscribed on prism BM $98972(+)$ BM 122617 + BM 127846 is generally thought to have been the earliest Babylon Inscriptions since it is the shortest of these texts. ${ }^{36}$ An early date of composition is plausible since passages describing events that occurred in Babylon before Esarhaddon became king (Episodes 3 and 5-7) are long and the building report (Episode 18) is short. ${ }^{37}$

Unlike the other known Babylon Inscriptions, the one copy of Babylon G adds the month during which that prism was inscribed: Ayyāru (II). This dating has led some scholars to believe that that copy of that text was writ-

\footnotetext{
32. Cogan, "Omens and Ideology," 85-86.

33. Porter, Images, Power, and Politics, 170-74.

34. In 1999, a clay cylinder clearly inscribed during that time was published, thereby providing concrete evidence that Esarhaddon had inscriptions written for Babylon between Ayyāru (II) 672 and Arahsamna (VIII) 669; see N. al-Mutawalli, "A New Foundation Cylinder from the Temple of Nabû," Iraq 61 (1999) 191-94 (= Leichty, Royal Inscriptions of Esarhaddon, 229-30 no. 113).

35. Royal Inscriptions of Esarhaddon, no. 112, which certainly dates to after 671 since Esarhaddon gives himself the title "king of the kings of [(Lower) Egypt], Upper Egypt, and [Kush]," is excluded here since that text may not be part of Esarhaddon's Babylon Inscriptions.

36. Leichty, Royal Inscriptions of Esarhaddon, 219-23 nos. 108-109. A. Millard ("Some Esarhaddon Fragments relating to the Restoration of Babylon," AfO 24 [1973] 118) suggested the nonphysical join between the two pieces. Col. ii 13 ii 13'-[24'] and 1"-18" duplicate Babylon B obv. 4'b-6' and 7'b-10' (ibid., 244-45 no. 116) with one minor textual variant (iktapud for èzizma).

37. For example, see Cogan, "Omens and Ideology," 86; and Porter, Images, Power, and Politics, 172.
} 
ten on that clay prism at the beginning of Esarhaddon's first regnal year (680), the assumed earliest possible date since that Assyrian king's less-than-a-month accession year did not have a month Ayyāru. However, based on information included in some of the Babylon Inscriptions themselves-the eleven-year period of abandonment after 689 and specific astronomical observations for Jupiter in the month Simānu (III) — that proposed date (II-680) is unlikely; that evidence suggests that Esarhaddon had not decided to rebuild Babylon and Esagil during his first regnal year. Since the heliacal rising of Jupiter observed at the end of Simānu (III) 679 may have been one of the key favorable omens prompting the Assyrian king to sponsor construction at Babylon, it is more likely that the Ayyāru in question was the very first one after the aforementioned auspicious celestial omen: the month of that name in the year 678 (Esarhaddon's third regnal year). The new proposed date is two years later than previously suggested. If Babylon $\mathrm{G}$ is the earliest of the known Babylon Inscriptions, then all of the other now-extant texts in this small corpus of texts must have been composed and written on clay foundation documents after Ayyāru (II) 678.

With nearly half of Babylon G preserved, it is fairly certain what the earliest Babylon Inscriptions contained and how the individual episodes were arranged, which in at least two cases differed from later texts. In addition to the building report (Episode 18 [and another episode]) being short and only describing the preparatory stages of the work at Babylon, the evidence for Babylon G being composed early in Esarhaddon's reign is four-fold. First, in Episode 1 (Esarhaddon's titulary), Esarhaddon referred to himself as malku na' du ša tarammu Zarpanitum "the pious ruler who is loved by the goddess Zarpanītu" (i 3'-4') and šarru šahtu ša bēlūssu<nu> putuqquma "reverent king who was attentive to their rule" (i $\left.6^{\prime}-8^{\prime}\right)$; the latter passage also appears in the 82-3-23,55 text. ${ }^{38}$ In later inscriptions, Babylon A for example, he called himself rubû na' du narām Zarpanìtum "the pious prince, the beloved of the goddess Zarpanitu" (i 9b-10) and šarru šahtu ša ultu ūmē șehrrišu bēlūssunu putuqquma "reverent king who from the days of his childhood was attentive to their rule" (i 12b-15a). ${ }^{39}$ Both epithets in Babylon G are certainly earlier versions of those in Babylon A.

Second, the wording and placement of Episode 11 (tasks assigned by Marduk to Esarhaddon) in Babylon G differed from those of later Babylon Inscriptions. This episode (i 13'-24') in Babylon G is placed between Episodes 1 (the king's name and titulary; i $1^{\prime}-12^{\prime}$ ) and 2 (the observation of inauspicious omens in Akkad; i 25'-27'); this arrangement also appears in Babylon B and the 82-3-23,55 text..$^{40}$ In the later Babylon A inscription, for example, Episode 11 (ii 9b-23a) is placed after Episodes 2-10. ${ }^{41}$ The contents of this episode differ greatly between Babylon $\mathrm{G}$ and the later Babylon Inscriptions. The relevant passage in Babylon G (i 13'-24') reads:

You (are the one) who entrusted him with renovating the de[st]royed shrines, making the cult [cen]ters shine, and shepherding all of the people; elevated him to the kingship to organize well the forgotten rites and to avenge Akkad; (and) to appease the heart of your [gre] at divinity (and) to please your spirit, [you] chose him for power. ${ }^{42}$

The corresponding passage in Babylon A (ii 9b-23a), for example, has:

You truly selected me, Esarhaddon, in the assembly of my older brothers to put these matters right, and you (are the one) who placed your sweet [pro]tection over me, swept away all of my enemies like a flood, killed all of my foes and made me attain my wish, (and), to appease the heart of your great divinity (and) to please your spirit, you entrus[ted] me with shepherding Assyria. ${ }^{43}$

38. Leichty, Royal Inscriptions of Esarhaddon, 222 no. 109.

39. Leichty, Royal Inscriptions of Esarhaddon, 195 no. 104; see also ibid., 203 no. 105 i 8-9 and 11-15.

40. Respectively Leichty, Royal Inscriptions of Esarhaddon, 222 no. 109 i 1'-29', 244-25 no. 116 obv. 1'-rev. 1, and 247 no. 117 obv. $1-12$.

41. Leichty, Royal Inscriptions of Esarhaddon, 194-97 no. 104 i 1-ii 33; see also ibid., 203-4 no. 105 i 1-iii 9 and 231-37 no. 114 i 1-iii 15.

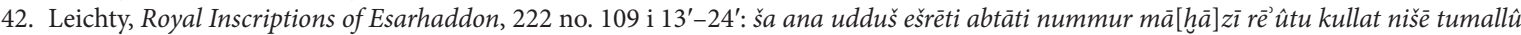
qātuššu ana šutēšuri pelludê mašûti u turri gimilli māt Akkadi taššŝšu ana šarrūti ana nuhhhu libbi ilūtika [rabī]ti šupšuh kabattika [tas]suqušu ana dannūti.

43. Leichty, Royal Inscriptions of Esarhaddon, 196 no. 104 ii 9b-23a: yâti Aššur-ahu-iddina aššu epšêti šināti ana [aš] rišina turri ina puhur 
Despite the many differences between the two versions of Episode 11, there is one significant clue indicating that Babylon $\mathrm{G}$ is earlier than Babylon A: this is the absence of the mention of Esarhaddon being selected as heir to Assyria rather than one of his older brothers. This biographical fact about the king-being a younger son of Sennacherib-was likely part and parcel of Esarhaddon's image after his seventh regnal year (674), when he and his armies were soundly defeated in Egypt. This aspect of his nomination as king was highlighted in particular in the lengthy prologue of Nineveh A (see below). ${ }^{44}$

Third, Episodes 3-4 (descriptions of the deeds of the Babylonians that angered Marduk) are long; these passages are also long in Babylon B. This section of text begins in the middle of col. i (i 25') and continues to the middle of col. ii ([24']); that is approximately fifty-five lines of text (about seventy-five words). ${ }^{45}$ In later Babylon Inscriptions, Babylon A for example, those two episodes tended to be short (thirty-six words). ${ }^{46}$ The abridgment of Episodes 3-4 in later texts was presumably to make room for longer building reports. In Babylon G (and Babylon B), these passages could be long since the account of construction at Babylon was short, as the work had only just begun.

Fourth, Babylon G ends with Esarhaddon's petition to the god Marduk (Episode 39); this text does not have concluding formulae (Episode 41). ${ }^{47}$ In later inscriptions, Esarhaddon's petition is addressed to the god Marduk and the goddess Zarpanitu and those texts end with advice to future rulers (Episode 41). ${ }^{48}$

There is little doubt that Babylon $G$ is presently is the earliest extant Babylon Inscription. ${ }^{49}$ This is one thing that most scholars can agree upon. This inscription must have been written before Babylon B since the building report of the former (Episode 18 [and other episode]) describes the work carried out before the actual construction began, while that of the latter (Episodes 19-20, 22, 24, 26, 34, and 37) records the early stages of the rebuilding of Esagil, including the making of bricks and laying of foundations.

\section{Babylon B and 82-3-23,55}

Two other inscriptions that were certainly written early in Esarhaddon's reign are Babylon B and the 82-323,55 text. ${ }^{50}$ An early date of composition is fairly certain for Babylon B since: (1) this text (obv. $7^{\prime} \mathrm{b}-10^{\prime}$ ) partially duplicates Babylon G (ii 2'-18'); ${ }^{51}$ (2) Episodes 3-4 (the sinful deeds of the citizens of Babylon and the looting of Esagil), 5-6 (the abandonment of Babylon by Marduk), 7-9 (the destruction of Babylon and its aftermath), and 12-14 (the observation of auspicious omens) are lengthy, just as they are in Babylon G; and (3) the building report (Episodes 19-20, 24, 26, and 34) is short and primarily concerns itself with the preparatory and early stages of building, in particular the making of bricks and laying of Esagil's foundations. The absence of the mention of Babylon's walls Imgur-Enlil and Nēmed-Enlil is also notable. Thus, based on parallels with Babylon G and on the contents of the extant text, it is likely that Babylon B is the second earliest known inscription in this subcorpus of texts. Although the beginning of this text is missing-if it is assumed that the text written on 82-3-23,55 actually

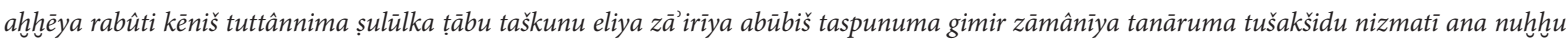
libbi ilūtika rabìti šupšuh kabattika rē ût mät Aššrur tumal[lû] qätüa.

44. See A. Knapp, "Royal Apologetic in the Ancient Near East" (PhD diss., Johns Hopkins University, 2012), 258-68. Knapp argues that the prologue of Nineveh A (Leichty, Royal Inscriptions of Esarhaddon, 11-15 no. 1 i 1-ii 39) was not composed in connection with the succession arrangement of 672, but rather to reconfirm his legitimacy after he failed to conquer Egypt.

45. See appendix 1 i 25'-ii [24'] and Leichty, Royal Inscriptions of Esarhaddon, 244 no. 116 obv. 1'-6'; ii 13'-[24'] duplicate Babylon B obv. $4^{\prime} \mathrm{b}-6^{\prime}$.

46. Royal Inscriptions of Esarhaddon, 195-96 no. 104 i 18b-33; see also ibid., 203 no. 105 i 20-37a.

47. Appendix 1 v 14'-7"'.

48. Leichty, Royal Inscriptions of Esarhaddon, 199-201 no. 104 vi 1-vii 43 and 208-10 no. 105 vii 42b-x 33.

49. The earliest extant Babylon Inscriptions were all excavated at Nineveh or are generally assumed to have come from there.

50. Leichty, Royal Inscriptions of Esarhaddon, 243-47 nos. 116-117. Both are preserved on fragments of wide, single-column clay tablets; it is not certain if $\mathrm{K} 192(+) \mathrm{K} 4513$ and 82-3-23,55 belong to one and the same tablet or are parts of different tablets and whether they are parts of the same or different inscriptions.

51. Respectively Leichty, Royal Inscriptions of Esarhaddon, 244-45 no. 116 and 220 no. 108. 
belongs to another inscription-it is fairly certain that Babylon B placed Episode 11 (the list of tasks that Marduk entrusted to Esarhaddon) between Episodes 1 (the king's name and titulary) and 2 (the observation of inauspicious omens during a previous reign). This arrangement of Episodes 1, 2, and 11 appears to only occur in the earliest known Babylon Inscriptions. In later texts, Episode 11 is placed after Episodes 2-10. ${ }^{52}$ Thus, a tentative date of ca. late 678 to 677 (or 676) is given here for the composition of Babylon B. If the statement about Esarhaddon having bricks made for an entire year (Episode 22) is true-and not a literary topos echoing Enüma eliš Tablet VI line 60, šattu ištât libittašu iltabnū-then 677 (or 676) seem more likely a date of composition than $678 .^{53}$

The text written on tablet fragment 82-3-23,55-assuming that it is not the very beginning of Babylon B-is probably also one of the earliest of the known Babylon Inscriptions since the arrangement of its extant contents is the same as those of Babylon B and Babylon G: Episode 11 is placed between Episodes 1 and $2 .{ }^{54}$ In addition, a variant in one of the king's epithets (Episode 1) and the wording of Episode 11 point to the 82-3-23,55 text being one of the earlier Babylon Inscriptions. As for the variant in Episode 1, 82-3-23,55 (line 3') has [̌̌arru šah]tu ša bēlūssunu pu[tuqquma], "[rever]ent [king] who was at[tentive to] their rule"; this variant also appears in Babylon G (i 6'-8'). $6^{55}$ The corresponding epithet in Babylon A (i 12b-15a) is šarru šahtu ša ultu ūmē șehrrišu bēlūssunu putuqquma, "reverent king who from the days of his childhood was attentive to their rule." ${ }^{56}$ As for Episode 11, the inscription written on 82-3-23,55 (lines 5'-8'a) has:

$[(\ldots)$ you (are the one) who entrusted] him [with renovating] the destroye[d s]hrines [... or]ganizing well the [forgotten] rites [... app] easing the heart of your great divinity. ${ }^{57}$

The contents of Episode 11 are similar to that same episode in Babylon G (i 13'-24'); $;^{58}$ it is quite different from the corresponding passage in Babylon A (ii 9b-23a). Although only the first twelve lines of the text written on 82-323,55 are preserved, this inscription may have been composed ca. late 678 to 677 (or 676).

\section{MMA 86.11.283}

An inscription preserved on a fragment of an eight-sided prism (MMA 86.11.283) appears to have been a Babylon Inscription that was written sometime between the aforementioned inscriptions (Babylon G, Babylon B, and the 82-3-23,55 text) and Babylon A. ${ }^{59}$ Most of what is extant of this text more or less duplicates the contents of Babylon A, as well as other later Babylon Inscriptions (Babylon C-D and F). ${ }^{60}$ This text being is earlier in date than Babylon A can be determined by the fact that the MMA 86.11.283 text contains shorter versions of Episodes 3-4 (events of a previous reign), 28 (the construction of Esagil), 32 (the repair of divine statues), and 37 (the reinstating of Babylon's privileged status).

52. Compare Leichty, Royal Inscriptions of Esarhaddon, 222 no. 109 i 1'-29', 244-45 no. 116 obv. 1'-rev. 1, 247 no. 117 obv. 1-12 to $194-97$ no. 104 i 1-ii 33, 203-4 no. 105 i 1-iii 9, and 231-37 no. 114 i 1-iii 15.

53. Respectively Leichty, Royal Inscriptions of Esarhaddon, 246 no. 116 rev. 13b; and W. G. Lambert, Babylonian Creation Myths, MC 16 (Winona Lake, IN: Eisenbrauns, 2013), 112. Compare Cogan, “Omens and Ideology," 85; and Porter, Images, Power, and Politics, 172.

54. See n. 40 .

55. Respectively Leichty, Royal Inscriptions of Esarhaddon, 247 no. 117 and 222 no. 109.

56. Leichty, Royal Inscriptions of Esarhaddon, 195 no. 104.

57. Leichty, Royal Inscriptions of Esarhaddon, 247 no. 117 lines 5'-8'a: [(...) ša ana udduš e] šrēti abtāti [... ana šu]tēšur pelludê [mašûti ... ana nu]ḩhu libbi ilūtika rabī[ti ... tumallù qāt $]$ ušš $u$.

58. Leichty, Royal Inscriptions of Esarhaddon, 222 no. 109.

59. Leichty, Royal Inscriptions of Esarhaddon, 225-26 no. 111; and Leichty and Spar, The Ebabbar Temple Archive, 260-63 and pls. 122-125 no. 159.

60. The ending of the concluding formulae more or less duplicates the same passage in Babylon E. Compare Leichty, Royal Inscriptions of Esarhaddon, 226 no. 111 viii 1-3' and 217 no. 106 viii 47-56 to 201 no. 104 vii 34b-43. 
In Episodes 3-4, the MMA 86.11.283 text (i 1'-2' and 6'b-7') has an[na ulla ahāmeš] è [tappalū], "[they] were [answering each other] ye[s (for) no]" and [Esagil] èkal ilān[i], "[Esagil], the palace of the god[s]," but Babylon A (i 22-25 and 29-30a) has the longer anna u ulla ahāmeš ètappalū edabbubā surrāti ilānišina ìbukāma, "they were answering each other yes (for) no (and) were telling lies. They led their gods away and" and Esagil èkal ilāni ašar lā âri, "Esagil, the palace of the gods, an inaccessible place." ${ }^{61}$ In the building report (Episode 28), the inscription written on MMA 86.11.283 (v 3') has [arșip u] šaklil, "[I built (and) com]pleted (Esagil)," but Babylon A (iii 52-53a) has the marginally longer arșip ušaklilma ana ni[kilti] ušakkila, "I built (and) completed (Esagil), then I had it ingeni[ously] built." ${ }^{2}$ Episode 32 in the MMA 86.11.283 text (v $\left.11^{\prime}-14^{\prime}\right)$ is significantly shorter than it is Babylon A (iv 9-17). The former records that Esarhaddon repaired only Esagil's apotropaic figures, but the latter states that the Assyrian king repaired the ruined cult images/statues and the temple's dilapidated protective figures. ${ }^{63}$ Finally, Episode 37 (the restoration of Babylon's special privileged status) is shorter in at least one place in the MMA 86.11.283 text. This inscription (vi 11'b-13'a) has kidinnūssunu bațiltu ana ašriša utêr, "I restored their interrupted privileged status," but Babylon A (v 29-31) has the longer kidinnūssunu bațiltu ša ina qātī ipparšidu ana ašrišu utēr, "I restored their interrupted privileged status that had fallen into disuse." 64

Because the inscription written on MMA 86.11.283 consistently contains shorter versions of passages included in Babylon A (as well as Babylon C), especially the building report (Episodes 28 and 32), it is likely that this Babylon Inscription was written earlier in Esarhaddon's reign than Babylon A. This inscription was probably composed sometime after Babylon G, Babylon B, and the 82-3-23,55 text, perhaps ca. 676 (or 675) to early/mid-674 since its contents have much in common with those of Babylon A and other later Babylon Inscriptions (Babylon C-D and F).

\section{Babylon A}

This Babylon Inscription, which is known from several damaged exemplars, is one of the best known texts in this subcorpus of this Assyrian king's official inscriptions. Babylon A appears to have been composed during the middle of Esarhaddon's reign, and not near the beginning of his reign as previously thought. ${ }^{65}$

Although Babylon A is not complete, most of its contents duplicate those of Babylon $\mathrm{C}$ verbatim. There are three major differences between the two inscriptions: (1) the building report of Babylon C includes a statement about the reinforcement of Esagil's structure (Episode 29) and a description of work on the cellas of Marduk, Zarpanìtu, and Nabû (Episode 30), but Babylon A does not; (2) Babylon C has a substantially shorter account of the renovation of the cult images/statues than Babylon A (Episode 32); and (3) Babylon C adds a sixteen-word passage (Episode 36) stating that Esarhaddon returned plundered gods to their proper place, whereas Babylon A does not. ${ }^{66}$ The last passage is particularly significant since several chronographic texts state the Assyrian king had some of those deities returned at the end of his seventh regnal year (674). ${ }^{67}$ The absence of this accomplishment likely indicates that Babylon A was written prior to the last month of Esarhaddon's seventh regnal year or was written early in his eighth regnal year (673). The return of these deities is regarded here as the terminus ante quem for Babylon $\mathrm{A}$ and the terminus post quem for Babylon $\mathrm{C}$ and Babylon $\mathrm{F}$.

61. Respectively Leichty, Royal Inscriptions of Esarhaddon, 225 no. 111 i 1'-10' and 195 no. 104 i $18 \mathrm{~b}-33$.

62. Respectively Leichty, Royal Inscriptions of Esarhaddon, 226 no. $111 \mathrm{v} 1^{\prime}-4^{\prime}$ and 198 no. 104 iiii $41 \mathrm{~b}-\mathrm{iv}$ la. Like Babylon A, this text does not include passages describing Esarhaddon reinforcing the structure and working on the cellas.

63. Compare Leichty, Royal Inscriptions of Esarhaddon, 226 no. 111 v 10'-11' to 198 no. 104 iv 8-18.

64. Respectively Leichty, Royal Inscriptions of Esarhaddon, 226 no. 111 vi 11'-15' and 195 no. 104 v 29-33.

65. Leichty, Royal Inscriptions of Esarhaddon, 194-201 no. 104. Babylon A ex. 6 is now regarded as part of Babylon F; see appendix 2. Porter (Images, Power, and Politics, 172) proposes that Babylon A was composed ca. 680-678.

66. Compare Leichty, Royal Inscriptions of Esarhaddon, 198-99 no. 104 iv 1b-17 and v 1-10 to 206-08 no. 105 v 10-46 and vi 33-vii 11.

67. Grayson, Assyrian and Babylonian Chronicles, 84 no. 1 iv 16-18 and 126 no. 14 rev. 20-22. XII-10-674 corresponds to February $23,673$. 
Now that a terminus ante quem for this text has been established, it is necessary to determine how early in Esarhaddon's reign Babylon A could have been composed. A principal clue for dating the text appears in Episode 11, a passage listing the tasks that the god Marduk expected Esarhaddon to perform as king. Babylon A ii 9b-23a records that Esarhaddon was selected to be king even though he had older brothers. Specifically, Babylon A ii 9b-14 states yâti Aššur-ahu-iddina aššu epšēti šināti ana [aš] rišina turri ina puhur aḩhēya rabûti kēniš tuttânnima, "you truly selected me, Esarhaddon, in the assembly of my older brothers to put these matters right." ${ }^{8}$ This reference to him being a younger son of Sennacherib is significant since Esarhaddon did not start promoting this image of himself until after he had suffered a major defeat in Egypt, when he tried to invade that country for the first time; that unsuccessful campaign is recorded in one Babylonian chronicle, in the entry for Esarhaddon's seventh regnal year (674).$^{69}$ Esarhaddon being one of Sennacherib's younger sons is best known from the prologue of the Nineveh A inscription (i 1-ii 39). ${ }^{70}$ That passage in Nineveh A has traditionally been regarded as being closely associated with the succession arrangement of the year 672, but, based on the dated copies of that inscription, that interpretation is not as certain as scholars believe it is. ${ }^{71}$ Recently, A. Knapp has proposed that Nineveh A's lengthy prologue was written after a disastrous defeat in Egypt to reemphasize his own nomination as king, a decision of his father that was supported by the gods. ${ }^{72}$ An essential part of this change in Esarhaddon's image appears to have been the highlighting of the fact that he was one of Sennacherib's younger sons. If the reference in Babylon A ii 13-14 to Esarhaddon being selected as heir instead of one of his older brothers is part of this ideological shift, then this Babylon Inscription may have been composed around the same time as Nineveh A, the earliest copies of which date to the early part of Esarhaddon's eighth regnal year (673). ${ }^{73}$ If this proposal proves correct, then Babylon A may have been composed sometime at the end of this king's seventh regnal year (674) or slightly later. However, if the mention of Esarhaddon being a younger son of the king proves not to be closely connected with the new image of the Assyrian king in the prologue of Nineveh A, then Babylon A could have been written earlier in Esarhaddon's reign, possibly during the early part of his seventh regnal (674) or even in his sixth regnal year (675). Scribes may have composed Babylon A ca. late 674 to early 673.

\section{Babylon $C$}

There is little difficulty in providing a terminus post quem for the longest extant edition of Esarhaddon's Babylon Inscriptions, Babylon C, which is known from two fragmentarily preserved exemplars. ${ }^{74}$ Since the Assyrian king states in this text that he had some plundered Babylonian gods returned from Assyria and Elam, it is certain that Babylon C could not have been composed before the end of Esarhaddon's seventh regnal year (674). ${ }^{75}$ Most scholars generally accept this late date of composition. ${ }^{76}$ Since the return of the gods to Agade in Addaru (XII) 674 can be established as Babylon C's terminus post quem, it may have been a few months after the actual event before that

68. Leichty, Royal Inscriptions of Esarhaddon, 196 no. 104. (XII).

69. Grayson, Assyrian and Babylonian Chronicles, 84 no. 1 iv 16. The Assyrian army is reported to have be defeated on the fifth of Addaru

70. Leichty, Royal Inscriptions of Esarhaddon, 11-15 no. 1.

71. For the connection of the prologue of Nineveh A to the nomination of Ashurbanipal and Šamaš-šuma-ukīn as heir designates of Assyria and Babylon respectively, see in particular H. Tadmor, "Autobiographical Apology in the Royal Assyrian Literature," in Tadmor and Weinfeld, History, Historiography and Interpretation, 38-45.

72. For a discussion of the issue, see Knapp, "Royal Apologetic," 258-68 (with references to previous literature).

73. Nineveh A exs. 2 and 6 are dated to IV?-673. See Leichty, Royal Inscriptions of Esarhaddon, 26 no. 1 vi 75B and 75D; see also n. 15.

74. Leichty, Royal Inscriptions of Esarhaddon, 202-10 no. 105.

75. Leichty, Royal Inscriptions of Esarhaddon, 208 no. 105 vii 5-11. Grayson, Assyrian and Babylonian Chronicles, 84 no. 1 iv 16-18 and 126 no. 14 rev. $20-22$

76. See, for example, Cogan, "Omens and Ideology," 85-86; and Porter, Images, Power, and Politics, 170-74, esp. 171. 
accomplishment of the Assyrian king was incorporated into the building reports of his Babylon Inscriptions. Thus, the earliest that that text could have been composed was either early or mid-673.

There is one piece of evidence that may suggest that Babylon C could have been composed slightly later than the middle of Esarhaddon's eighth regnal year: the reference to the renovation of the temple of Nabû-of-the-har $\hat{u}$ (Eniggidrukalamasuma) at Babylon in v 23-38a. ${ }^{77}$ Work on that temple is known from the building report of an inscription written on a clay cylinder (IM 142109); that object was discovered in the south wall of the cella of that Nabû temple. ${ }^{78}$ Since that text mentions that Ashurbanipal and Šamaš-šuma-ukin were the heir designates of Assyria and Babylon respectively, it is certain that Esarhaddon was working on Nabûs temple during the period between Ayyāru (II) 672 and Arahsamna (VIII) 669. Therefore, it is not impossible that Babylon C was composed at the beginning of the 672-669 period or immediately before it. Thus, it is plausible that Babylon C's date of composition is ca. mid-/late 673 to early $672 .^{79}$

\section{Babylon F}

A second Babylon Inscription, Babylon F, records that the Assyrian king returned plundered gods to Babylonia and, for this reason, Esarhaddon's scribes cannot have been composed this text before the end of $674 .{ }^{80}$ Although only about one-third of it is preserved, it is certain that Babylon $\mathrm{F}$ was written on clay prisms around the same time as Babylon C, that is, ca. mid-/late 673 to early 672 .

However, it is not known with certainty if Babylon F was composed earlier or later than Babylon C since those two inscriptions presently appear to deviate in only one passage. Episode 37-the passage recording the good deeds that Esarhaddon performed on behalf of the wronged citizens of Babylon (Episode 37) - ends in Babylon C (vi 41b-42a) with ippušu takbittu, "so that they could establish an important position." ${ }^{81}$ In Babylon F (iii' 17-24), this episode adds dalihtu? ša Kiš? [u]taqqinma niše [dal]hāte [u]šeseŝu [n] üru, "[I re]stored order to [the dist]urbances at Kish and [ma]de [li]ght shine forth for the [con]fused people" after ippušü takbittu. Given the fact that Babylon A is damaged at this point, it is not known if Babylon C shortened Episode 37 to make room for Episode 30 -a sixty-four-line expansion of the building report (v 16-38a) — or if Babylon F expanded this episode. ${ }^{82} \mathrm{Had}$ Babylon A been better preserved at the end of Episode 37 and at the beginning of Episode 39 (petition to Marduk and Zarpanitu), one might be able to figure out the chronological sequence of Babylon C and Babylon F.

\section{MMA 86.11.277}

Too little of the inscription written on fragment MMA 86.11.277 is preserved to be able to properly assess its date of composition. ${ }^{83}$ Since its extant contents duplicate passages included in Babylon A and Babylon C, this text must have been composed during the same period, or perhaps slightly earlier. A general date of ca. 676 (or 675) to early 672 is tentatively suggested here for the MMA 86.11.277 text.

\footnotetext{
77. Leichty, Royal Inscriptions of Esarhaddon, 206 no. 105, with Nabû mentioned in v 25 and 37.

78. Leichty, Royal Inscriptions of Esarhaddon, 229-30 no. 113, lines 20-28a in particular.

79. Compare the comments of Porter, Images, Power, and Politics, 172.

80. Leichty, Royal Inscriptions of Esarhaddon, 194 and 199-201 no. 104 (ex. 6) and 217-19 no. 107; and Leichty and Spar, The Ebabbar Temple Archive, 265-70 and pl. 127 no. 161. This inscription is known from a single exemplar now comprising three fragments. For details on the join between BM 78247 and MMA 86.11.342 (+) CBS 1526, see appendix 2.

81. Leichty, Royal Inscriptions of Esarhaddon, 199 no. 105.

82. The last preserved line of Babylon A ex. 4 reads [ka]-bit-tu [...] "[im]portant [...]." It is not known if that word was followed in Babylon A by Marduk "Marduk" (like Babylon C) or by dalihtu? "disturbances" (like Babylon F).

83. Leichty, Royal Inscriptions of Esarhaddon, 223-24 no. 110; and Leichty and Spar, The Ebabbar Temple Archive, 263-65 and pl. 126 no.
} 160. 


\section{Babylon D}

Lord Aberdeen's Black Stone has been generally thought to have been composed early in Esarhaddon's reign, 680 (Esarhaddon's second regnal year) or shortly thereafter. ${ }^{84}$ However, an early date of composition for Babylon D is unlikely. This text was probably written much later in the reign, ca. late 673 to 672 (or later) since (1) its prologue mentions the god Nabû, a deity whose temple at Babylon was being rebuilt during the $672-669$ period; (2) its short building report gives the impression that construction was either in an advanced stage of completion or nearing completion; and (3) certain passages have more in common with Babylon E (one of the latest Babylon Inscriptions) than with Babylon A and Babylon C.

Although most of the contents of Babylon D duplicate with some minor variation Babylon A and Babylon C, there are several clues that this text was composed later than both of the aforementioned inscriptions. ${ }^{85}$ First, the nineteen-word passage listing Esarhaddon's titles and epithets (i 1-6; Episode 1) duplicates the corresponding

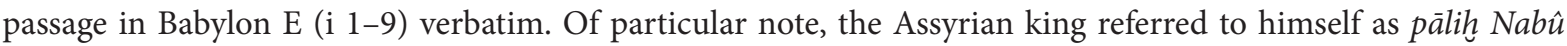
u Marduk "the one who reveres the gods Nabû and Marduk." 86 This reference to Nabû may refer to the Assyrian king rebuilding the temple of Nabû-of-the-ḩarû. It is certain from the inscription written on IM 142109 that Esarhaddon was working on Eniggidrukalamasuma ("House which Bestows the Scepter of the Land") during the 672-669 period. References to work on Nabû's temple in Babylon C (v 24-25 and 36-38a) suggest that construction on this temple may have already begun in 673 (Esarhaddon's eighth regnal year). Second, Babylon D, Babylon E, and the inscription written on IM 142109 begin the passage describing events that took place in the reign of a previous ruler (Episode 2) with ullânü a, "before my time," whereas this episode begins with inūšu "at that time" in earlier inscriptions. ${ }^{87}$ Third, Babylon D (ii 9b-11) states in Episode 9 that the people living in Babylon were ana șindi u birte $z u^{\prime \prime} u z \bar{u}$ illikū rēšùtu, "distributed among the (foreign) riffraff (and) became slaves." Babylon E (i 32-ii 3) uses the exact same wording, but Babylon A (ii 47b-ii 2a) records that those same people were ašar šanâmma

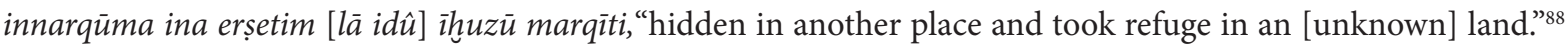
And fourth, Babylon D (iv 16-28; Episode 23) sums up in thirty-three words the work carried out on Esagil, its sanctuaries, and the inner and outer walls of Babylon (Imgur-Enlil and Nēmed-Enlil), rather than having lengthy descriptions of those four projects as Babylon A (iii 41b-v 9; Episodes 24-28 and 31-35) does. ${ }^{89}$ That passage (Episode 23) in Babylon D reads:

I had Esagil, the palace of the gods, and its shrines, Babylon, the privileged city, Imgur-Enlil, its wall, (and) NēmedEnlil, its outer wall, built anew from their foundations to their parapets. I made (them) greater (than before), raised (them) up, (and) glorified (them). I refurbished the statues of the great gods (and) I had (them) dwell on their daises as an eternal dwelling. I (re)confirmed their interrupted sattukku-offerings. ${ }^{90}$

84. Leichty, Royal Inscriptions of Esarhaddon, 231-37 no. 114. This object is a unique, polished black basalt cuboid monument that was purchased by the fourth Earl of Aberdeen sometime around the 1820s and presented to the British Museum (London) in 1860. For the proposed early dating of the inscription, see Porter, Images, Power, and Politics, 171

85. Many passages included in Babylon A and Babylon C are omitted in Babylon D, which is due in part to the limited space available on the monument itself and due in part to the intended message of the inscription.

86. Respectively Leichty, Royal Inscriptions of Esarhaddon, 231 no. 114 and 212 no. 106.

87. Compare Leichty, Royal Inscriptions of Esarhaddon, 212 no. 106 i 10, 229 no. 113 line 8, and 231 no. 114 i 8 a to 195 no. 104 i $18 \mathrm{~b}$ and 203 no. 105 i 20 a.

88. Respectively Leichty, Royal Inscriptions of Esarhaddon, 231-36 no. 114, 212 no. 106, and 195-96 no. 104.

89. Respectively Leichty, Royal Inscriptions of Esarhaddon, 237 no. 114 and 198-99 no. 104.

90. Leichty, Royal Inscriptions of Esarhaddon, 237 no. 114 iv 16-28: Esagil ēkal ilāni u ešrētišu Bābili āl kidinni Imgur-Enlil dūršu Nēmed-Enlil šalhûš̌u ultu uššěšun adi naburrī̌šn eššiš ušépiš ušarbi ušaqqi ušarriḩ șalam ilāni rabûti uddiš ina parakkišsunu ušarmâ šubat dārâti sattukkiššnu bațlīti ukin. 
B. N. Porter regarded Babylon D's building report (Episode 23) as being one of the earliest accounts of the work carried out at Babylon since the thirty-three word passage dealt with the construction in a cursory manner. ${ }^{91}$ However, this is not the case since this passage gives the impression that the work in Babylon was beginning to wrap up or was at least in an advanced state of completion. The passage in Babylon E describing the rebuilding of Esagil (iii 38-47; Episode 26), although it does not duplicate Babylon D iv 16-28 (Episode 23) verbatim, is similar in style and content. Thus, these two inscriptions were likely written at approximately the same time, with one inscription borrowing from the other. In particular, compare Babylon D iv 16-17 and 21-24 (see above) to Babylon E iii $38-47:^{92}$

I built anew (and) [co]mpleted Esagil, the palace of the gods, together with its shrines, from its foundations to its battlements. I made (it) greater than before, raised (it) up, glorified (it).

If Babylon E is regarded as being a late composition, then so too should Babylon D. But how late in Esarhaddon's reign was Babylon D composed? This is not an easy question to answer given the lack of firm historical references. Since Nabû is mentioned in this text (i 5b-6), which may allude to the renovation of temple of Nabû-of-the-hyar $\hat{u}$ at Babylon, and since it is known that the Assyrian king was working on Eniggidrukalamasuma between Ayyāru (II) 672 and Arahsamna (VIII) 669, Babylon D may well have been composed from late 673 to very early Ayyāru 672 or during the $672-669$ period itself, possibly sometime in Esarhaddon's ninth regnal year (672). Because most of the contents of Babylon D duplicate those of Babylon A and Babylon C, this text is regarded here as being earlier in date than Babylon E, which has little in common with Babylon A and Babylon C. Therefore, Lord Aberdeen's Black Stone may have been inscribed ca. late 673 to 672 .

\section{Babylon $E$}

This Babylon Inscription, which is known from several exemplars (including a clay tablet), is generally regarded as having been composed ca. 674 or later. ${ }^{93}$ As discussed already in the previous section, Babylon E is probably even later in date, ca. 672 to early $670 .{ }^{94}$ Babylon $\mathrm{E}$ is either the latest or second latest known text in this subcorpus of Esarhaddon's official inscriptions; it is not known if Babylon E is earlier or later than the IM 142109 text.

With regard to its contents, Esarhaddon's scribes more or less completely reworked the contents of the previous Babylon Inscriptions; very little of the wording of Babylon A, Babylon C, and Babylon D made it into Babylon E. The reasons for this major overhaul are not known, but it is likely that construction at Babylon was nearing completion and that the Assyrian king was feeling much more confident about completing the projects in that city than he was earlier in his reign. Therefore, he no longer needed to verbosely justify his decision to rebuild Babylon and Esagil to Marduk. ${ }^{95}$

91. Porter, Images, Power, and Politics, 171-72.

92. Respectively Leichty, Royal Inscriptions of Esarhaddon, 231 and 236 no. 114 and 214 no. 106. Babylon E iii 38-47 reads: Esagil ēkal ilāni adi ešrētišu ultu uššěšu adi naburrī̌su ěššš arșip [u]šaklil eli ša ū $[m \bar{e}]$ pāni ušarbi ušaqqi ušarrih.

93. Leichty, Royal Inscriptions of Esarhaddon, 211-17 no. 106; and Leichty and Spar, The Ebabbar Temple Archive, 257-60 and pl. 121 no. 158. The long-known international join between exs. 2 and 6 was overlooked in Royal Inscriptions of Esarhaddon; ex. 7 now joins exs. $2+6$. For the date, see in particular Porter, Images, Power, and Politics, 171.

94. The later date is suggested here on the basis of a Neo-Assyrian letter (K 930; S. Parpola, Letters from Assyrian and Babylonian Scholars, SAA 10 [Helsinki: Helsinki University Press, 1993], 200 no. 253) referring to the addition of an intercalary Ulülu $\left(\mathrm{VI}_{2}\right)$ and the postponement of an akitu-festival at Babylon. Parpola (ibid.) dates that letter to the first of Ulūlu (VI), 670 (Esarhaddon's tenth regnal year). If that dating proves correct, then Esagil must have been in an advanced stage of completion for Esarhaddon to have been considering returning Marduk's statue and taking his hand during an akitu-festival. That postponed festival never occurred since Esarhaddon died before he was able to return Marduk to Babylon.

95. Compare the comments of M. Cogan (“Omens and Ideology," 82-84). He suggests this text's composers represented either a proAssyrian and antidivinatory position or were rationalists who did not view omens and fortune-telling as vital to royal policies. 


\section{IM 142109}

The inscription written on IM 142109, a solid cylinder inscribed with a text stating that Esarhaddon rebuilt the temple of Nabû-of-the-ḩarû, was clearly composed during the period between Ayyāru (II) 672 and Arahsamna (VIII) 669 since Ashurbanipal and Šamaš-šuma-ukin are named as heir designates of Assyria and Babylonia respectively. ${ }^{96}$ Its chronological relationship to Babylon D and Babylon F is not known.

\section{Conclusions}

As the de facto ruler of Babylon, Esarhaddon's authority over Sumer and Akkad was recognized, but he never took the hand of the god Marduk during an akitu-festival since that god was in exile in the city Ashur and not in a position to confer kingship. Thus, this Assyrian king could not officially begin counting his regnal years as ruler of Babylon. This put the king and his image-makers in a bit of a quandary since scribes in the employ of the Assyrian king usually added the month, day, and year to the clay foundation documents (prisms and cylinders) they had inscribed. Scribes were not in a position to date inscribed objects intended for Babylon by the king's regnal years since that might have angered Marduk since that god had not yet officially conferred the kingship of Babylon on Esarhaddon; they could, however, do this for inscriptions written on prisms and cylinders intended for projects undertaken in Assyrian cities, Ashur and Nineveh in particular. A solution to the problem was found and that was to date all inscribed objects, when a date was required, to Esarhaddon's accession year. The Assyrian king, as long as he had not taken the hand of the god Marduk during an akitu-festival at Babylon, could truthfully make that claim. Therefore, the use of šanat rēšs šarrūti as the date of the known Babylon Inscriptions reflects historical reality, and, thus, there is no longer any reason to assume that Esarhaddon's scribes deliberately falsified the dates of prisms and cylinders. Moreover, this method of dating is also a Babylonian one, rather than an Assyrian one since the Assyria dated documents by eponyms, rather than by regnal years. Thus, it is not a surprise that a Babylonian date is used for Esarhaddon's Babylon Inscriptions.

Since a dating to the accession year in Babylon could refer to any time between Addaru (XII) 681 and Arahsamna (VIII) 669, there is no longer any reason to assume that any of Esarhaddon's Babylon Inscriptions were composed during his (at most) twenty-two-day accession year in Assyria or immediately after he came to the throne. Babylon A-D are all explicit about the start date of the project to restore Babylon: the period of Babylon's abandonment was eleven years. If this statement is in fact true, then the eleven years would have been from the city's destruction in 689 (Sennacherib's sixteenth regnal year) to 679 (Esarhaddon's second regnal year). The year 679 as the end of that eleven-year period can be confirmed by the inclusion of a passage in several inscriptions (Babylon A-C) describing the observation of a heliacal rising of Jupiter in the month Simānu (III). Thus, it can be inferred from information provided in the texts themselves that Esarhaddon first gave serious consideration to undertaking construction at Babylon later than previously regarded by scholars. If this proves to be true, then none of the known Babylon Inscriptions could have been written before that time and, therefore, the one known copy of Babylon G was likely inscribed in Ayyāru (II) 678 (Esarhaddon's third regnal year), not long after the Assyrian king had decided to rebuild Babylon and Esagil.

The Babylon Inscriptions were composed and inscribed on clay and stone objects between Ayyāru (II) 678 and the end of his reign, with the latest texts probably being composed ca. 672 to early 670 . The chronological sequence of those twelve texts can be established from a careful examination of their contents, but their precise dates of composition can only be conjectural given the near absence of firm historical references. The relative order and suggested dates of Esarhaddon's Babylon Inscriptions are as follows:

96. Leichty, Royal Inscriptions of Esarhaddon, 229-30 no. 113. 
Inscription $(s)$
Babylon G
Babylon B, 82-3-23,55
MMA 86.11.283
Babylon A
Babylon C, Babylon F
MMA 86.11.277
Babylon D
Babylon E, IM 142109

\author{
Suggested Date of Composition \\ II-678 \\ ca. late 678 to 677 (or 676) \\ ca. 676 (or 675) to early/mid-674 \\ ca. late 674 to early 673 \\ ca. mid- to late 673 to early 672 \\ ca. 676 (or 675) to early 672 \\ ca. late 673 to 672 \\ ca. 672 to early 670
}

Of particular note, Babylon D, which was previously thought to have been the second earliest known Babylon Inscription, is in fact one of the latest texts in this group. It appears to have been composed about seven years later than previously proposed. Likewise, the copies of Babylon A were written several years later than previously thought. That text does not come from the first two or three years of Esarhaddon's reign, but somewhere in middle of it, closer to the end of his reign than the beginning of it.

Now that the chronological sequence of Esarhaddon's Babylon Inscriptions has been more or less established, further studies on the editorial techniques of royal scribes can be pursued. Although it was claimed nearly thirty years ago that the Babylon Inscriptions were at that time a well-plowed field of study, there is much that we can still learn about this small subcorpus of this Assyrian king's official texts.

\section{Appendix 1: New Edition of Babylon G}

Although BM 98972 and BM 122617 + BM 127846 have been regarded as belonging to the same prism since 1973, when A. Millard first published his copy and notes about the latter fragment in "Some Esarhaddon Fragments," 118-19 and pl. XIV, this fact was overlooked (or rejected) by E. Leichty in Royal Inscriptions of Esarhaddon. ${ }^{97}$ The author has verified Millard's non-physical join, thus confirming that BM 98972 and BM 122617+ come from the same five-sided prism. Because these three fragments have not yet been edited together as part of the same text, the author takes the opportunity here to do so, with some alternate readings and collations.

Parts of 147 lines of the approximately 275 lines of text are extant. ${ }^{98}$ BM 98972 preserves col. i $11^{\prime \prime}-16^{\prime \prime}$, ii $1^{\prime \prime}-18^{\prime \prime}$, iii $1^{\prime}-14^{\prime}$, iv $1^{\prime}-21^{\prime}$, v 1'"-11'. BM 122617+ preserves col. i $1^{\prime}-29^{\prime}$, ii $1^{\prime}-23^{\prime}$, and v $1^{\prime}-15^{\prime}$.

\section{Transliteration}

Col. i (Lacuna) ${ }^{\left(1^{\prime}\right)}$ rSIPA!7 $[k e-e-n u]^{\left(2^{\prime}\right)}$ mi-gir EN EN.[EN] ${ }^{\left(3^{\prime}\right)}$ ma-al-ku na-a $a^{\prime}-d u^{\left(4^{\prime}\right)}$ ša ÁG d zar-pa-ni-tum šar-ra-tu ${ }^{\left(5^{\prime}\right)}$ i-lat ka-la gim-ri ${ }^{\left(6^{\prime}\right)}$ LUGAL šah-tu ${ }^{\left(7^{\prime}\right)}$ ša be-lut-su-<nu> ${ }^{\left({ }^{\prime}\right)} p u$-tuq-qu-ma ${ }^{\left({ }^{\prime}\right)} q u-r u-u s-s u-n u$ da-al-lu ${ }^{\left(10^{\prime}\right)} r e-e-s ̌ u$

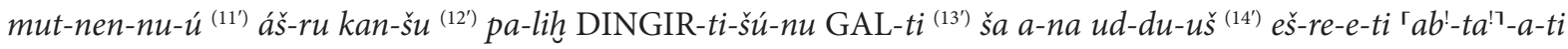
${ }^{\left(15^{\prime}\right)}$ nu-um-mur ma-[ha]-zi ${ }^{\left(16^{\prime}\right)}$ re-'u-ú-tu kul-lat UN.MEŠ ${ }^{\left(17^{\prime}\right)}$ tu-ma-al-lu-ú qa-tuš-šu ${ }^{\left(18^{\prime}\right)} a-n a$ šu-te-šu-ri pel-lu-

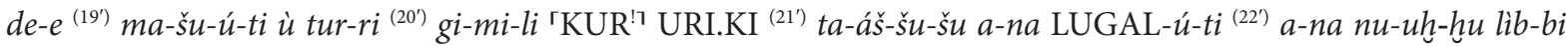

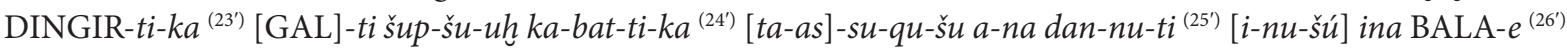
[LUGAL mah]]-ri-ia ${ }^{\left(27^{\prime}\right)}$ [it-tab-šá-a Á].MEŠ HUL.MEŠ ${ }^{\left(28^{\prime}\right)}$ [UN.MEŠ? kul-lat $\left.{ }^{?} m a ~ h a^{?}\right]-z i^{99}{ }^{\left(29^{\prime}\right)}$ [...] $x$ (Lacuna) ${ }^{\left(1^{\prime \prime}\right)}$

97. Leichty, Royal Inscriptions of Esarhaddon, 219-23 nos. 108-109. Note that RINAP generally edits objects not physically joined separately.

98. Each column may have contained approximately fifty-five lines. The count is based on the lines preserved in cols. i-ii.

99. See Millard, "Some Esarhaddon Fragments," 118. Most of the restorations in i 28' are based on Leichty, Royal Inscriptions of Esarhad- 


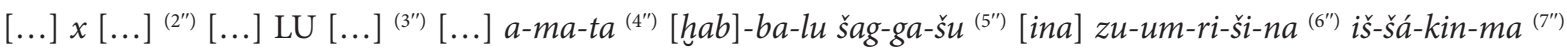
$[e n]-s ̌ u ~ i-h ̧ a b-b i-l u^{\left(8^{\prime \prime}\right)}[i]-s ̌ a r-r a-k u$ a-na dan-ni ${ }^{\left(9^{\prime \prime}\right)}$ ina qé-reb URU dul-lu-lu ${ }^{\left(10^{\prime \prime}\right)}$ ma-hyar kàd-re-e ${ }^{\left(11^{\prime \prime}\right)} i b-b a-s ̌ i-m a$

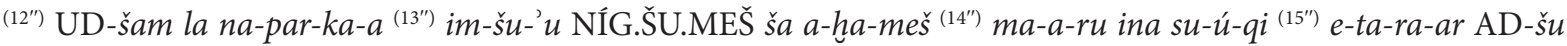
${ }^{\left(16^{\prime \prime}\right)} r e-e-\check{u} u$ a-na EN-šu

Col. ii (Lacuna) ${ }^{\left(1^{\prime}\right)} x[\ldots]^{\left(2^{\prime}\right)}$ par- $\left[s ̦ i-s ̌ i-n a^{?}\right]{ }^{\left(3^{\prime}\right)}$ ú- $\left.\left[m a s ̌-s ̌ i-r a-m a^{?}\right]^{100}{ }^{\left(4^{\prime}\right)} \check{s} a ́ \mathrm{BI} x^{!}[\ldots]^{\left(5^{\prime}\right)} n i-x[\ldots]\right]^{\left(6^{\prime}\right)}{ }^{\ulcorner} \mathrm{AN}^{\urcorner}[\ldots]$

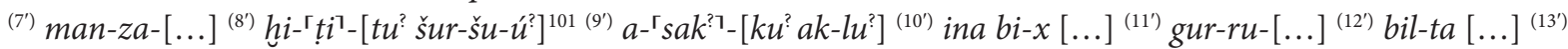

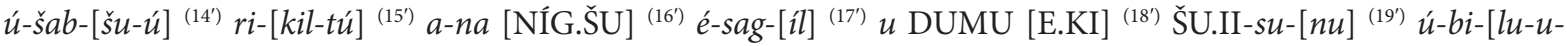

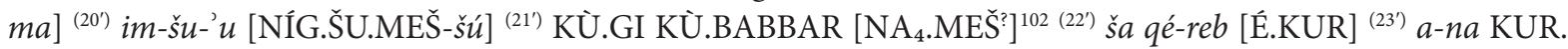

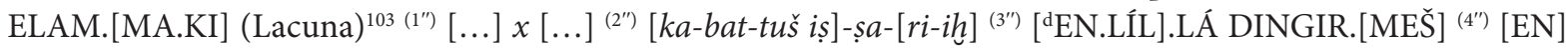
KUR.KUR ${ }^{\left(5^{\prime \prime}\right)} a-n a[s a]-p a h$ KUR $u$ UN.MEŠ ${ }^{\left(6^{\prime \prime}\right)} i k$-ta-pu-ud ${ }^{\left(7^{\prime \prime}\right)} l e-m u t-t u^{\left(8^{\prime \prime}\right)} a$-na sa-pan KUR ${ }^{\left(9^{\prime \prime}\right)} \dot{u}$ hul-lu-uq UN.MEŠ-šá ${ }^{\left(10^{\prime \prime}\right)} l i b-b u-u s{ }^{\left(11^{\prime \prime}\right)} i k-p u-u d-m a^{\left(12^{\prime \prime}\right)}$ ar-rat ma-ru-uš-ti $i^{\left(13^{\prime \prime}\right)} i \check{s}-\check{s} a ́-k i n^{\left(14^{\prime \prime}\right)} i n a$ pi-i-šu ${ }^{\left(15^{\prime \prime}\right)}$ ina AN-e u KI-tim ${ }^{\left(16^{\prime \prime}\right)}$ Á.MEŠ HUL-tim ${ }^{\left(17^{\prime \prime}\right)} i t-t a b-\check{s} a ́-a^{\left(18^{\prime \prime}\right)}$ šá ḩa-laq mit-ḩar-ti

Col. iii (Lacuna) ${ }^{\left(1^{\prime}\right)}[x(x)] x x^{\left(2^{\prime}\right)}[\mathrm{x}] x \mathrm{URU}^{\left(3^{\prime}\right)} \dot{u}$-šab-ši-ma ${ }^{\left(4^{\prime}\right)}$ GI.AMBAR.MEŠ ${ }^{\left(5^{\prime}\right)} \dot{u}$ GIŠ.șar-ba-ti ${ }^{\left(6^{\prime}\right)}$ ina qer-bi$\check{s ̌ u ́ u}^{\left(7^{\prime}\right)}$ ma-gal i-šir-ma ${ }^{\left(8^{\prime}\right)} \dot{u}$-ṣar-ri-šá ${ }^{\left(9^{\prime}\right)}$ pa-pal-lu ${ }^{\left(10^{\prime}\right)}$ MUŠEN.MEŠ AN-e ${ }^{\left(11^{\prime}\right)} \mathrm{KU}_{6}$.MEŠ ZU.AB ${ }^{\left(12^{\prime}\right)}$ ša la ni-bi $i^{\left(13^{\prime}\right)}$ ina $q e r-b i-\check{s}^{\left(14^{\prime}\right)} i b-b a-\check{s} u-m a$

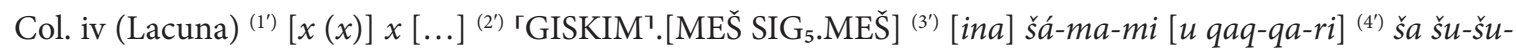
$[u b \mathrm{URU}]^{\left(5^{\prime}\right)} \dot{u} u d-d u-\left[u s ̌{ }^{\left(6^{\prime}\right)}\right.$ eš-re-e- $[t i-s ̌ u]^{\left(7^{\prime}\right)} i s ̌-t a p-p a-r a^{\left(8^{\prime}\right)}$ gis-kim-bu-uš ${ }^{\left(9^{\prime}\right)}$ ad-ke-e-ma ${ }^{\left({ }^{\left(10^{\prime}\right.}\right)}$ gi-mir um-ma-ni ${ }^{\left(11^{\prime}\right)}$ KUR.kar- ${ }^{\mathrm{d}} d u n$-iá-às ${ }^{\left(12^{\prime}\right)} k a$-la-ma ${ }^{\left({ }^{\left(13^{\prime}\right)}\right.}$ GIŠ.MEŠ u GI.AMBAR.MEŠ ${ }^{\left(14^{\prime}\right)}$ ina qul-mé-e ik-ši-țu ${ }^{\left(15^{\prime}\right)}$ is-su-ḩu šu-ru-us-su ${ }^{\left(16^{\prime}\right)}$ A.MEŠ ÍD.pu-rat-ti ${ }^{\left(17^{\prime}\right)} a b-b u$ iš-tu qer-bi-šú ${ }^{\left(18^{\prime}\right)} a p-r u-u s-m a^{\left(19^{\prime}\right)} a-n a m a-l a-k i-s ̌ u-n u^{\left(20^{\prime}\right)} m a h-r e-e^{\left(21^{\prime}\right)} u$ u-šar-di

Col. v (Lacuna) ${ }^{\left(1^{\prime}\right)}[\ldots]-x-u^{\left(2^{\prime}\right)}[\ldots]-s u^{\left(3^{\prime}\right)}[\ldots]-m a^{\left(4^{\prime}\right)}[\ldots]-x^{\left(5^{\prime}\right)}\left[t a-n i t^{?}\right]-{ }^{\top} t i^{\prime ? ~ d !}$ AMAR ${ }^{7}$.UTU ${ }^{\left(6^{\prime}\right)}\left[\mathrm{EN}^{\text {? }}\right.$ GAL- $\left.e^{?}\right]$

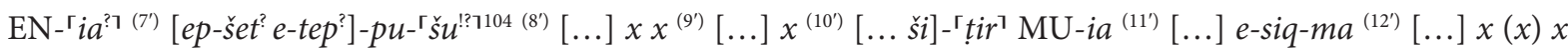

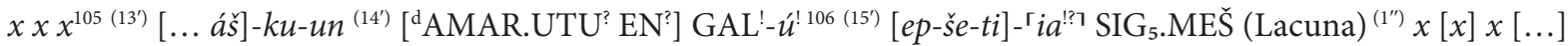
${ }^{\left(2^{\prime \prime}\right)} l i s ̌-s ̌ a ́-k i n ~ i n a ~ p i-[i-s ̌ u]^{\left(3^{\prime \prime}\right)} i k-r i b$ UD.MEŠ SÜ.[MEŠ] ${ }^{\left(4^{\prime \prime}\right)} l i k-r u-b a n-n i-m a^{\left({ }^{\prime \prime}\right)} \check{s} u-l u m$ BALA.MEŠ-ia ${ }^{\left(6^{\prime \prime}\right)} l i q-t a-b i$

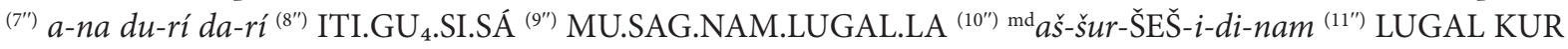
$a \check{s}-\check{u} u r . \mathrm{KI}$

\section{Translation}

(i $1^{\prime}-12^{\prime}$ ) [true] shep[herd], favorite of the lord of lord[s], pious ruler, the one who is loved by the goddess Zarpanitu - the queen, goddess of the entire universe - reverent king who was attentive to their rule and praised their valor, pious slave, humble, submissive, the one who reveres their great divinity-

(i $13^{\prime}-24^{\prime}$ ) You (are the one) who entrusted him with renovating the des[tro]yed shrines, making the cult [cen]ters shine, and shepherding all of the people; elevated him to the kingship to organize well the forgotten rites and to avenge Akkad; (and) to appease the heart of your [gre] at divinity (and) to please your spirit, [you] chose him for power.

(i $25^{\prime}-27^{\prime}$ ) [At that time], in the reign of [a king who prec]eded me, bad [omens occurred].

don, 247 no. 117 line 9 and on the assumption that this section began with nišü; see, for example, ibid., 195 no. 104 i 21 and 203 no. 105 i 23.

100. The tentative restorations in ii $2^{\prime}-3^{\prime}$ are based on Leichty, Royal Inscriptions of Esarhaddon, 244 no. 116 obv. 2'.

101. The tentative restorations in ii $8^{\prime}-9^{\prime}$ are based on Leichty, Royal Inscriptions of Esarhaddon, 244 no. 116 obv. $4^{\prime}$.

102. The tentative restoration in ii $21^{\prime}$ is based on Leichty, Royal Inscriptions of Esarhaddon, 225 no. 111 i $8^{\prime}$.

103. Based on parallels, the translation assumes that the now-missing ii $24^{\prime}$ contained ipšurü maḩiriš. In the short lacuna, possibly restore Leichty, Royal Inscriptions of Esarhaddon, 244 no. 116 obv. $7^{\prime}$.

104. The tentative restorations in $\mathrm{v} 5^{\prime}-7^{\prime}$ are based on collation and on Leichty, Royal Inscriptions of Esarhaddon, 224 no. 110 iii' $2^{\prime}-4{ }^{\prime}$.

105. Collation does not support the reading [... ši $]$-țir ${ }^{\mathrm{d}} 15 . \mathrm{MES}$ since the traces look more like [...] ${ }^{\mathrm{r}} \mathrm{KAL}$ BA/NA U A ${ }^{\top} x$.

106. The tentative restorations in $\mathrm{v} 14^{\prime}-15^{\prime}$ are based on collation and on a similar passage in Babylon C; compare Leichty, Royal Inscriptions of Esarhaddon, 208 no. 105 vii $42 \mathrm{~b}$-viii 2. Note also that the subject of the verbs in v 2", 3", 4", and 6" are all third person singular. The translation assumes that hadî̌ lippalisma appeared in the now-missing v $16^{\prime}$. 
(i 28'-29') [The people of all of the cult cent $]$ ers $[\ldots]$...

Lacuna

$\left(\right.$ i $\left.1 "-16^{\prime \prime}\right)[\ldots] \ldots[\ldots] \ldots[\ldots]$ matter. They were afflicted by [thie]ving (and) murdering. They were stealing from [the po] or (and) giving to the mighty; there was oppression (and) (i 10') the taking of bribes in the city. Every day, without ceasing, they stole goods from each other, a son (i $\left.15^{\prime \prime}\right)$ cursed his father in the street, a slave [...] to his owner,

Lacuna

(ii $\left.1^{\prime}-14^{\prime}\right) \ldots[\ldots]$ the $[y$ abandoned their $]$ ri $[$ tes and $] \ldots[\ldots] \ldots[\ldots] \ldots[\ldots] \ldots[\ldots$ they were inciting $]$ crimin $[$ al acts (and) infringing on] a tab $[o o]$, in ... [... ... [... ... [... (and) they] fomented a con[spiracy].

(ii 15'-23') [They] pu[t] th[eir] hands on [the possessions of] Esag[il] and the citizens of [Babylon, and] they plundered [its goods], gold, silver, (and) [stones] from inside [the temple (and) sold (it) at market value] to the land Elam.

Lacuna

(ii $1^{\prime \prime}-14^{\prime \prime}$ ) [...] ... [... his mood] became [furious. The Enlil] of the god[s, the lord of] the lands, plotted evilly to [scat]ter the land and people; his heart schemed to level the land and to destroy its people. A bitter curse was set in his mouth.

(ii 15"-18") Bad omens concerning the destruction of mankind occurred in heaven and on earth.

Lacuna

(iii $\left.1^{\prime}-14^{\prime}\right)[\ldots] \ldots[\ldots]$ He (the god Marduk) brought about [the destruction] of the city (Babylon); reed-marshes and poplars grew profusely in it and threw out many offshoots. There were birds of the heavens (and) fish of the apsû, without number, in it.

Lacuna

(iv $1^{\prime}-8^{\prime}$ ) [... ... [good si]gn[s were established for me; in] heaven [and on earth], he (the god Marduk) constantly sent me his omen(s) concerning the (re)settl[ing of the city] and the renovat[ion of its] shrines.

(iv $9^{\prime}-21^{\prime}$ ) I mustered all of the craftsmen throughout Karduniaš (Babylonia). They cut down the trees and reeds with axes (and) tore out their roots. I diverted the waters of the Euphrates River, the washout, from its midst and (re)directed (them) to their previous channels.

Lacuna

$\left(\mathrm{v} \mathrm{l}^{\prime}-13^{\prime}\right)[\ldots] \ldots[\ldots] \ldots[\ldots]$ and $[\ldots] \ldots[$ the glor $] y$ of the god $[\mathrm{Ma}] \mathrm{rduk}$, [the great lord], $m y$ lord, (and) [the deeds that I had do]ne $[\ldots] \ldots[\ldots] \ldots[\ldots$ the writin]g of my name $[\ldots]$ I depicted and $[\ldots] \ldots$ [I p]laced (them) [...].

(v 14'-15') [May the god Marduk, the] great [lord, look with joy upon m] y good [deeds and]

Lacuna

(v 1"-7") Let ... [...] be placed in [his] mouth; let him (the god Marduk) bless me with a blessing of long days (and) order the well-being of my reign forever.

(v 8"-11") Ayyāru (II), accession year of Esarhaddon, king of Assyria.

\section{Appendix 2: New Edition of Babylon F}

Since 1896, Babylon F has been known from only a single fragment: BM 78247, a fragment of a clay prism in the British Museum (London) that is registered as coming from Hillah. ${ }^{107}$ Its script is Neo-Assyrian and it was thought to have been part of an eight-sided prism, with the piece coming from the top of three columns. As it turns out, BM 78247 belongs to the same prism as MMA 86.11.342 (+) CBS 1526, a large prism fragment in the Metropolitan

107. See Leichty, Royal Inscriptions of Esarhaddon, 217-19 no. 107 and 238-43 no. 115 ex. 3 (with references to earlier literature). 


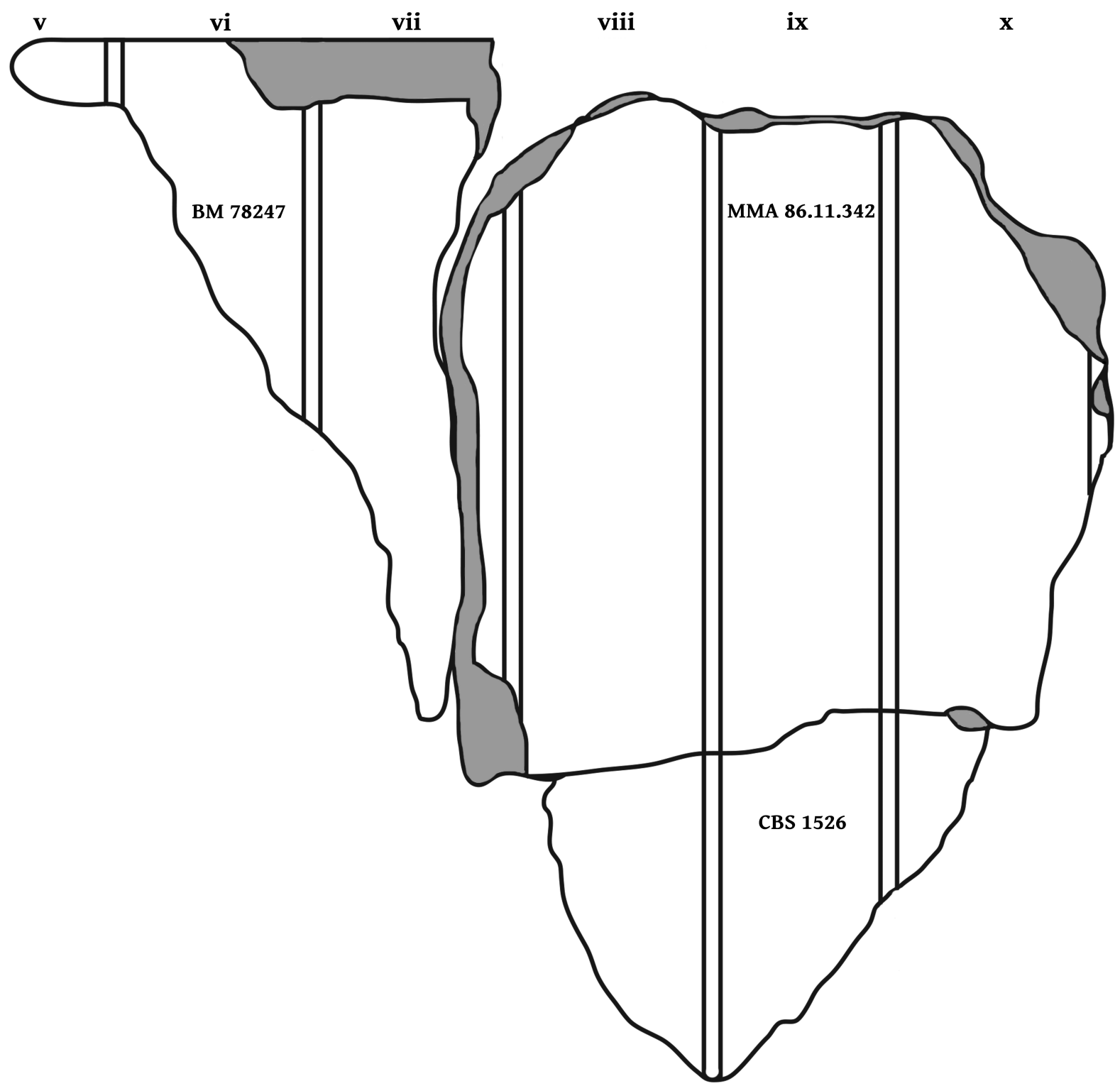

Fig. 1. Schematic drawing of the proposed joins between BM 78247, MMA 86.11.342, and CBS 1526.

Museum of Art (New York) and a small fragment in the University of Pennsylvania Museum of Archaeology and Anthropology (Philadelphia). ${ }^{108}$ The joined New York and Philadelphia pieces were regarded as being an exemplar of Babylon A since the contents of col. i' 13'-19' deviated from Babylon C and, thus, that passage was regarded as filling in part of a gap then missing in Babylon A. ${ }^{109}$ BM 78247 col. iii' 7-25 joins MMA 86.11.342+ col. i' 1'-19'.

108. See Leichty, Royal Inscriptions of Esarhaddon, 193-201 no. 104 ex. 6 (with references to earlier literature); and Leichty and Spar, The Ebabbar Temple Archive, 265-70 and pl. 127 no. 161.

109. In Babylon $\mathrm{C}$, the passage recording the good deeds Esarhaddon performed on behalf of the citizens of Babylon ends with ippuš $\bar{u}$ takbittu, "they could establish an important position" and is immediately followed by a lengthy petition to Babylon's tutelary deities, an episode 
The join was recognized by the author on the basis of the shape of the pieces, the script, and the narrow width of the columns. ${ }^{110}$ The author takes the opportunity here to present a new edition of Babylon $\mathrm{F}$.

The three pieces preserve parts of the last six columns of a tall, solid ten-sided clay prism. Parts of 160 lines of the approximately five hundred lines of text inscribed on the prism are extant. BM 78247 preserves col. i' $1-3$, ii' $1-14$, and iii' $1-27$. MMA 86.11 .342 preserves col. iii' 7-25, iv' $1^{\prime}-25^{\prime}, v^{\prime} 1^{\prime}-23^{\prime}$, and vi' $1^{\prime}-22^{\prime}$. CBS 1526 preserves col. iv' $26^{\prime}-43^{\prime}, v^{\prime} 23^{\prime}-42^{\prime}$, and vi' $23^{\prime}-32^{\prime}$.

\section{Transliteration}

(Beginning of inscription missing)

Col. $i^{\prime(1)}\left[n a b-n i t^{?}\right]$ KÙ.GI ${ }^{(2)}$ [šá 50 MA.NA].TA.ÀM ${ }^{111(3)}$ [KI.LÁ]-šú-nu (Lacuna) ${ }^{112}$

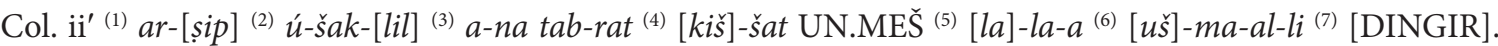

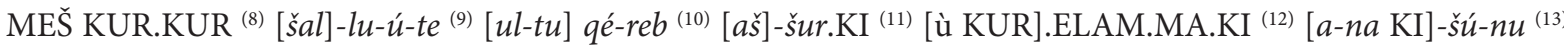
[ú]-ter ${ }^{(14)}$ [ù ina kul]-lat (Lacuna) ${ }^{113}$

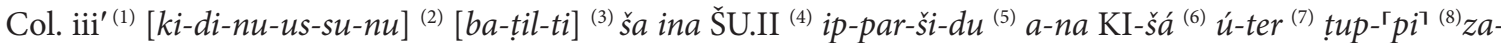

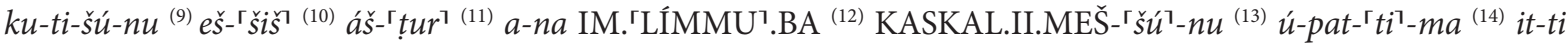

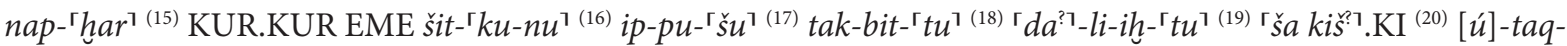

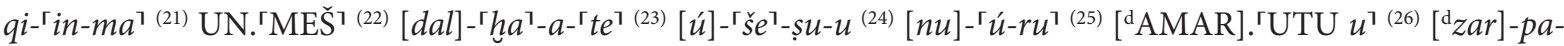
$n i-\left[\text { tum] }{ }^{(27)}[\text { DINGIR.MEŠ }]^{114} \text { (Lacuna) }\right)^{115}$

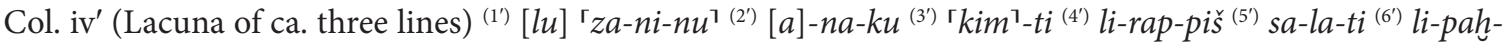

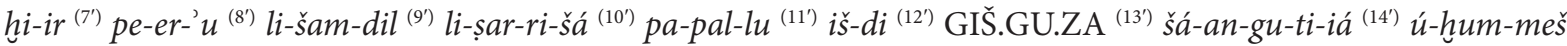

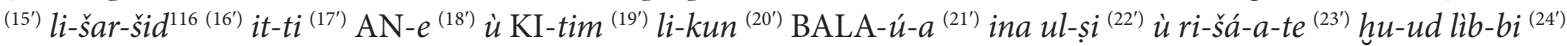

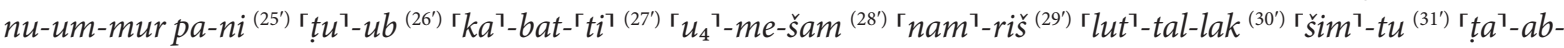

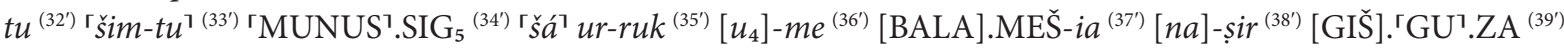

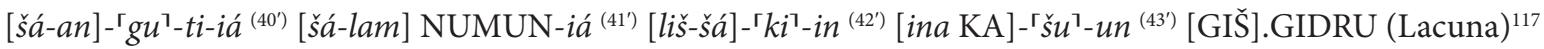

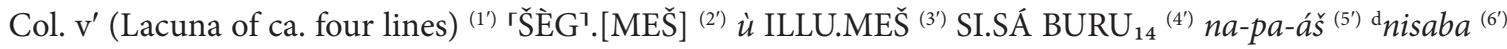

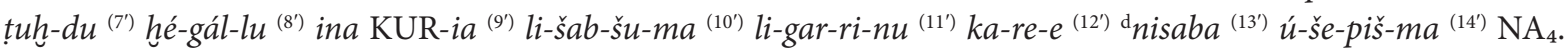

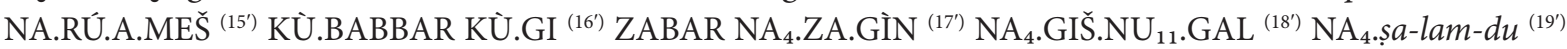

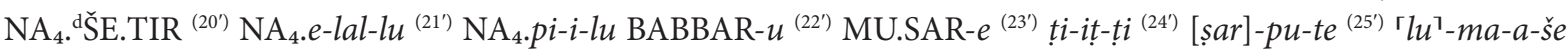

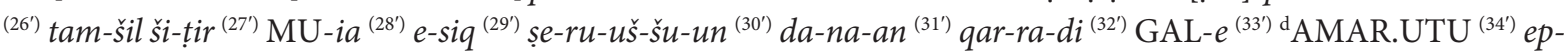

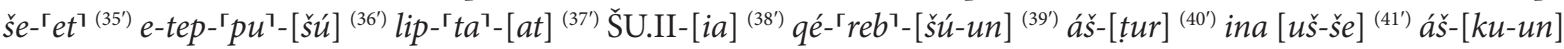
${ }^{(42)} a-[\text { na }(s a-a t)]^{118}$ (Lacuna) $)^{119}$

that began with Marduk u Zarpanitum "the god Marduk and the goddess Zarpanitu." Compare Leichty, Royal Inscriptions of Esarhaddon, 208 no. 105 vii $41 \mathrm{~b}-43$ to 199 no. 104 v $37 \mathrm{~b}-45$.

110. Ex. 6 should be removed from the catalogue of Leichty, Royal Inscriptions of Esarhaddon, 194 no. 104.

111. There may not be enough space at the beginning of $i^{\prime} 2$ to restore KÜ.BABBAR. It is uncertain if Babylon F (intentionally or accidentally) omitted this word or if it appeared before KÜ.GI in i' 1, in place of nab-nit.

112. For the potential contents of the lacuna between i' 3 and ii' 1, see Leichty, Royal Inscriptions of Esarhaddon, 207 no. 105 vi 9-42a. At the end of col. i', one can restore with certainty no. 105 vi 33-42a (ibid.).

113. Between ii' 14 and iii' 1, restore Leichty, Royal Inscriptions of Esarhaddon, 199 no. 104 v 10-28 and 208 no. 105 vii 10b-33a.

114. The line is preserved on the prism, but only the blank space between the now-missing DINGIR and MEŠ remains.

115. Between iii' 27 and iv' 1', restore Leichty, Royal Inscriptions of Esarhaddon, 200 no. 104 vi 1-14 and 208-9 no. 105 viii $1 \mathrm{~b}-20$.

116. The signs should be read as li-šar-šid, and not as li-ter-ra. Royal Inscriptions of Esarhaddon, no. 105 ex. 1 viii 27 should be read as uhummeš lišaršid, and not as uhummeš literra. The reading is supported by Royal Inscriptions of Esarhaddon, no. 104 ex. 1 vi 21 ([uhummeš lišar $]$ šid).

117. Between iv' 43 and v' 1', restore Leichty, Royal Inscriptions of Esarhaddon, 200 no. 104 vi 34b-42 and 209 no. 105 ix 1b-13.

118. Based on other lines, both $a$ - $[n a]$ and $a$-[na sa-at $]$ are possible.

119. Between v' 42' and vi' 1', restore Leichty, Royal Inscriptions of Esarhaddon, 201 no. 104 vii 18b-24a and 210 no. 105 ix 36b-x 7. 


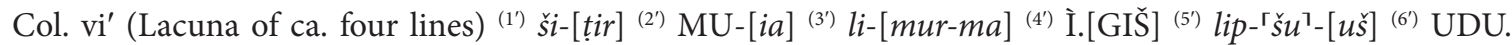
[SÍSKUR] ${ }^{\left(7^{\prime}\right)} l i q-[q i]^{\left(8^{\prime}\right)} a-[n a]^{\left(9^{\prime}\right)}$ KI- ${ }^{r s ̌ u} u^{\left({ }^{\left(10^{\prime}\right)}\right.} l u$-ter ${ }^{\left(11^{\prime}\right)}$ dAMAR.UTU ${ }^{\left(12^{\prime}\right)}$ LUGAL DINGIR.MEŠ ${ }^{\left(13^{\prime}\right)} i k-r i-b i-s ̌ u ́$

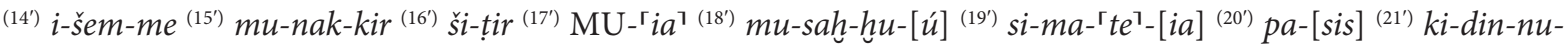
[tú] ${ }^{\left(22^{\prime}\right)}$ KÁ.DINGIR.RA.[KI] ${ }^{\left(23^{\prime}\right)} p a-[t i r]{ }^{\left(24^{\prime}\right)} r i-[k i s]{ }^{\left(25^{\prime}\right)}$ EN EN.[EN] ${ }^{\left(26^{\prime}\right)}$ dAMAR.[UTU] ${ }^{\left(27^{\prime}\right)}{ }^{d}$ EN. ${ }^{\ulcorner L I L}{ }^{7}$.[LA ${ }_{5}{ }^{\left(28^{\prime}\right)}$ DINGIR.[MEŠ] ${ }^{\left(29^{\prime}\right)}$ EN [KUR.KUR] ${ }^{\left({ }^{\prime} 0^{\prime}\right)} e z-[z i-i \check{s}]^{\left(31^{\prime}\right)} l i k-[k i l-m e-s ̌ u ́-m a]^{\left(32^{\prime}\right)}$ ina $[$ nap-har $]$ (Lacuna) ${ }^{120}$

\section{Translation}

Beginning of inscription missing

(i' 1-3) [from] gold, [each of] who[se weight is fifty minas].

Lacuna

(ii' 1-6) I bui[lt] (and) comple[ted Nēmed-Enlil, its outer wall, (and) had] (it) filled with [spl]endor, (making it) an object of wonder for [al]l of the people.

(ii' 7-14) [I] returned [the plun]dered [god]s of the lands [from As]syria [and the land] Elam [to] their [place] and [I set up proper procedures in a]ll of [the cult centers].

Lacuna

(iii' 1-24) I restored [their interrupted privileged status] that had fallen into disuse. I wrote anew the tablet of their exemptions. I opened roads for them in all directions so that they could establish an important position by having (commercial) relations with all countries. [I re]stored order to [the dist] urbances at Kish and [ma]de [li]ght shine forth for the [con]fused people.

(iii' 25-27) [The god Mard]uk and [the goddess Zar]panī[tu, the gods],

Lacuna

Lacuna of ca. three lines

(iv' $1^{\prime}-2^{\prime}$ ) I am [indeed] the provider.

(iv' $3^{\prime}-42^{\prime}$ ) Let me enlarge my [fa]mily, gather my relatives, (and) extend my progeny so that they branch out widely; let him (the god Marduk) make the foundation of the throne of my priestly office be as secure as a great mountain; let my reign endure as long as heaven and earth; let me stride beaming daily in joy, gladness, happiness, shining face, (and) [ha]ppy mood; (and) [let] a happy fate, a good fate, (one) for the lengthening of [the d]ays of my [reign, the prote]ction of [the th] rone of my [pries]tly office, (and) [the well-being of] my offspring [be pl]aced [in] their (the gods') [mouths].

(iv' 43') [The sc] epter

Lacuna

Lacuna of ca. four lines

$\left(\mathrm{v}^{\prime} 1^{\prime}-12^{\prime}\right)$ Let them allow there to be in my land rain $[\mathrm{s}]$ and floods, successful harvests, an abundance of grain, plenty, and prosperity, and let them store (it) in piles of grain.

$\left(\mathrm{v}^{\prime} 13^{\prime}-42^{\prime}\right)$ I had foundation inscriptions made of silver, gold, bronze, lapis lazuli, alabaster, basalt, pend $\hat{u}-$ stone, elallu-stone, (and) white limestone, (as well as) inscribed objects of [ba]ked clay, and (then) I depicted on them hieroglyphs representing the writing of my name. I wr[ote] on [them] the might of the great hero, the god Marduk, (and) the dee[ds that] I had do[ne], [my] pious wo[rk], (and) I pl[aced] (these inscriptions) in [the foundations] (and) fo[r far-off days].

Lacuna

Lacuna of ca. four lines 
(vi' $1^{\prime}-14^{\prime}$ ) May he (a future king) r[ead an inscription] wri[tten in] my [name, and] anoi[nt] (it) with o[il], $\mathrm{ma}[\mathrm{ke}]$ an of[fering], (and) return (it) to it[s] place. The god Marduk, king of the gods, will (then) hear his prayers.

$\left(v^{\prime} 15^{\prime}-32^{\prime}\right)$ (As for) the one who changes (an inscription) written in my name, defac[es my] representatio[ns], an[nuls] the privileged sta[tus of] Babylo[n], (and) bre[aks] the cove[nant of] the lord of lo[rds], may the god Mar[duk], the Enl[il of] the god[s], the lord of [the lands], lo[ok with] fu[ry on him and among [all].

Lacuna 